\title{
Analysis of Political Parties Representation in Parliament Influence Public Policy Formulation in Uganda's Nascent Hydrocarbon Industry
}

\author{
Mulyanyuma Aaron Ayeta $^{1 *}$, Were Edmond Maloba ${ }^{1}$, Okoth Pontian Godfrey ${ }^{2}$ \\ ${ }^{l}$ Kisii University, Kenya \\ ${ }^{2}$ Masinde Murilo University of Science \& Technology (MMUST), Kenya
}

*Corresponding Author: Mulyanyuma Aaron Ayeta, Kisii University, Kenya

\begin{abstract}
This study examined political parties' representation in parliament influencing public policy formulation (at agenda setting) in Uganda's nascent hydrocarbon industry. The study followed both a research objective and hypothesis. The researcher applied a descriptive cross-sectional survey research design to guide the study. The research adopted both quantitative and qualitative approaches and data was collected from 218 respondents selected out of 490 Members of Parliament. The researcher collected both quantitative and qualitative data which was analyzed using descriptive and inferential statistics and thematic content analysis respectively. The findings revealed that political parties' representation is a significant determinant of public policy formulation in Uganda's nascent hydrocarbon industry. It was concluded that there is a strong positive relationship between political parties' representation and public policy formulation in Uganda's nascent hydrocarbon industry. It is recommended that political parties should emphasize party discipline and numbers in order to increase seats in parliament. Political parties should emphasize discipline among their members such that they toy the party line and vote according to the caucus decision; political parties should always endeavor to increase their numbers in parliament in order to influence public policy formulation.
\end{abstract}

Keywords: Agenda setting, Hydrocarbons, Political parties, Public policy formulation.

\section{INTRODUCTION}

\subsection{Background of the Problem}

In Africa, new political leaders deliberately banned political parties activities after independence and little political competitions existed. Public policy making was left to the presidents of the time who ruled by Decree or dictated upon by the Executive in a single-party system. But Carbone (2005) argues that the new political leaders had the desire to consolidate political power with an excuse that political parties could encourage ethnic divisions. However, Torill (1999) contends that political parties are virtually indispensable features of modern democratic governance. Kakuba (2010) explains that the period from 1962 to 2006 witnessed political parties' dysfunction and failed public policy in Uganda. Political parties could not offer hope to Ugandans since their mandate was peripherized and limited by political regimes in power at the time. Political and economic development in Uganda remained a dream and public policy formulation platform dominated by state machinery.

According to African Election Database, Uganda has 29 registered political parties. Mpyisi \& Mwirichia, (2011) explain that out of the 29 political parties, 27 are new and recognizes DP and UPC as old far back in 1950s and 1960s respectively. It is reported that among the 29 registered political parties only four are more vibrant: National Resistance Movement (NRM), Forum for Democratic Change (FDC) Democratic Party (DP) and Uganda Peoples' Congress (UPC) that have consistently fielded candidates during elections since 2006 National elections (Carley-Baxter et al., 2009). Kasimbazi, (2012) observes that between 1985 and 2013 has witnessed the development of a legal framework in Uganda's hydrocarbon industry. The first Petroleum and Production Act was developed in 1985 (Namuyondo, 2013). The research study covered the period of ten covering three national elections (2006-2011; 2011-2016). Policy debates gained momentum after 2005 referendum (Dawkins, 2017). This study was conducted in Uganda and its major focus was how NRM, FDC, DP and UPC contribute to policy formulation in the Parliament of Uganda. 


\subsection{Importance of the Problem}

Public policy formulation for the nascent hydrocarbon industry in Uganda is a responsibility of parliament where various political parties are represented. However, the influence of political parties in formulation of policies that guide the exploration and exploitation of hydrocarbons in Uganda tends to be insignificant. This situation is exacerbated by the predominance of the Executive that should focus on policy implementation. The dynamics in their political parties consist of conflicts in political parties' unequal political parties' representation.

\subsection{Literature Review}

Parliament as the legislative branch of government and oversees the administration of public policy that responds to needs. Parliamentary oversight role is intended to hold government accountable in respect of how public funds are spent. The political party's guide ignores facts political parties are faced with to qualify these assumptions. However, this study concentrated on the ideal situations and did not pay attention to challenges Parliaments are facing to deliver their mandate. The politics of policy making remain relevant at agenda setting stage in multiparty politics (Yamamoto, 2007).

According to Hix (2002) political parties shape public policy process since they adhere to party policy decisions. In multi-party democracy, political parties formulate policy proposals that respond to public needs. Most European countries have embraced multiparty democracy and political parties present better policy options in Parliament to guide decision-making. Hindmoor et al., (2009) contend that policy decisions approved by parliament are based on policy demands viewed as a response to political demands presented to parliament by political parties. Political parties are considered significant contributors to public policy formulation process in representative democracy. The policy decisions approved by Parliament are based on policy demands viewed as a response to political demands presented to Parliament by political parties. In Western Europe, political parties shape policy direction by adhering to political parties' decisions (Lord, 2010).

According to Hai (2013), a policy problem should exist and policy choices must be made and making political parties relevant in public policy process. Political parties present policy proposals to the floor of parliament as policy alternatives to government policy proposals where parliament is to choose from and approve them for implementation. Public policy formulation involves is a strategy used by policy analysts to evaluate policy alternatives to address public demands. However, scholars like Chigora et al., (2011) assert that in many young democracies, opposition parties lack concrete policy alternatives which are evidence-based to build a case in parliament challenging government policy proposals due to limited technical expertise or limited research. This presents political parties as weak non-institutional actors in public policy process.

According to Carbone (2003), opposition parties are important political institutions that help to engage government/the ruling party in policy debates concerning issues of public concern. The opposition position raise policy related matters for discussion in Parliament. Parliament is composed of both major and minority political parties with divergent policy agenda. Political parties play an oversight role and check on government actions and propose policy alternatives.

Alemán\& Tsebelis (2011) explain that in developed democracies, political parties play the following roles: they provide policy alternatives, presenting candidates to contest and win elections, providing social cohesion and finally, vetting and training political leaders to assume political offices. Political parties played a fundamental role in early 1887 to organize and present the political needs of the citizens to government. It has been noted that for sustainability of political parties, both internal and external factors that affect party functionality need to be addressed. Political parties need to allow for internal democracy to flourish thereby enhancing party political cohesion. The respect for party structures would enhance internal party democracy. Other factors would include: the two-way communication and reporting relationships promoted.

Scholars like Curini et al., (2018) explain that political parties need numerical strength to influence public policy process in parliament as the saying goes, "the majorities have their way and the minorities have their say". However, Gould \& Winters (2012) noted that political parties are either weak or none functional and only surface during election time and hardly influence public policy process especially in developing democracies. This gives the ruling governments advantage to manipulate the policy process to serve their own interests. 
According to Marcel (2016), the hydrocarbon industry is a new field of study across the globe and political parties have had challenges in regard to public policy making in many countries. Eggers \& Spirling (2015) argue that opposition parties should device strategies to control the dominance of ruling parties in Parliament through lobbying, forming coalitions and alliances that could result into adoption of alternative policies to guide the hydrocarbon industries. But Jinadu (2011) contends that public policy formulation is a function of political parties and calls for dialogue and negotiations between the ruling party and opposition parties. The ruling government in Uganda continues to overshadow and limit the functionality of the opposition parties in the policy process. Bainomugisha (2006) affirmed that political parties in Uganda continue to fight for political space and confirm their relevancy not only for political leadership positions but also in public policy formulation.

Juma (2011) explains that the relevance of opposition parties in developing democracy is thin due to many challenges they face. The capacity to fundraise to funds party activities and programs is a challenge (Rose-Ackerman, 2004). Ssemogerere (2011) explains that in Uganda, opposition parties are frustrated by the ruling party. Parties are denied political space and state funding as a strategy to weaken them. The intern parties' coherence is also a big challenge to opposition parties in Uganda (Schmidt, 2002). Parties in Uganda are a doubt for political transition. Political organizations will only survive and thrive if they address internal party contradictions.

Scholars such as Liebig et al., (2014) argue that public policy formulation process is an initiative of government in power and has nothing to do with opposition parties. Public policy formulation is universal and it cannot be attributed to political party influence per se but other actors. Political parties in many developing countries have remained seasoned institutions and their role in public policy continues to diminish (Cross \& Young, 2008). It is highly debatable if governments in developing democracies like Uganda consider political parties as partners in public policy making process. The reviewed literature indicates that the functionality of political parties is highly limited and as such little attention has been paid to policy making process in hydrocarbon industry in oil producing countries.

Scholars like Kiiza (2005) and Osabiya (2015) note that the mandate of political parties includes: representation, law-making and oversight in Parliament. Political parties actively participate and influence public policy formulation process if they win majority seats in national elections. There is a fear that the ruling party will always influence the policy direction in parliament. According to Bernstorff (2007), law-making and oversight performance are functions of political parties. Political parties perform legislative mandate to evaluate the performance of government.

According to Banfield (2011), parliament provides the legislative framework for contractual deals. However, Pojani et al., (2011) note that the functions of the Parliamentary Committees of Natural Resources, are affected by information gap among members of the Parliamentary Committee about the management of the nascent hydrocarbon industry. Despite their increasing importance in policy development, political parties are extremely limited in executing policy mandate by the Executive branch of government which tremendously influences policy making in the hydrocarbon industry.

Maiyo (2017) argues that political parties in Uganda have had limited relevance in public policy formulation due to political ban which was instituted by the NRM government from 1986 to 2005 . The performance of historical parties like UPC, DP and Conservative Party (CP) could not be measured. Party activities like: holding party meetings, conferences, mobilizing members, fundraising were banned rendering them weak and irrelevant in matters of public policy making. The opposition leadership in Uganda is expected to mobilize the citizens to participate and benefit from government programmes (Svein-Erik, 2011). Political parties in developed democracies influence policy agenda and provide policy opinion especially in the hydrocarbon industry (Takeshita, 2006).

Steinack (2011) attests that in case there are many political parties with limited number of Members of parliament that affect public policy formulation process on contentious policy proposals, application of dialogue can be used to form coalitions to achieve formulation of policies that benefit the entire nation. But Jans \& Piedrafita, (2009) argue that the legislative roles of parliament are possible to fulfill if Members of Parliament as party representatives cooperate with other political parties to in the country. Laver (1997) contends that public policy formulation is a major focus of political parties since their roles are linked to actions of government through adoption and approval of public policy proposals pledged during elections. Daley (2014) explains that government needs a 
parliamentarian majority to influence public policy formulation where the bills under contention are subjected to voting.

\subsection{Research Question and Hypothesis}

The researcher opted to use both inferential and descriptive statistics as a way of triangulating the research results.

\subsubsection{Research Question}

- How do political parties representation in Parliament influence public policy formulation in nascent hydrocarbon industry in Uganda?

\subsubsection{Hypothesis}

- $\quad \mathbf{H}_{0}$ : Political parties' representation in Parliament does not influence public policy formulation in nascent hydrocarbon industry in Uganda.

\section{MeThODOLOGY}

\subsection{Research Design}

The researcher adopted a descriptive research design. A descriptive research also called survey research (Creswell, 2009). The researcher selected respondents from a cross section of political organizations in Uganda. Neuman (2013) explains that in a cross-sectional research study, the researcher selects respondents who differ on one key characteristic at one specific point in time.

The personal philosophical position of the researcher is that of a positivist but a qualitative approach was employed for triangulation purposes (Mazaki, 2017). Quantitative data were collected from 209 (95.9\%) respondents, while qualitative data were collected from 9 (4.1\%) respondents and this implies that the present study is largely quantitative. This design was also preferred because according to Creswell (2009) the survey research design is useful in collecting views from a large sample.

The cross sectional design was employed, where data were gathered and described from different categories of respondents from various political parties in Uganda. The Bivariate correlations were used to measure the relationships between political parties' influence and Uganda's public policy formulation in the nascent hydrocarbon industry. The regression analysis was used to predict the Members of Parliament responses in statistics on political parties' influence (independent variable) and public policy formulation (dependent variable).

The study was descriptive in that the researcher described the phenomenon and data that were collected were analyzed in relation to political parties' representation in parliament influence on Uganda's public policy formulation process (Vetter, 2017). The researcher used inferential statistics to determine the relations the two variables. The survey was considered because data were gathered from a sample of the different groups of respondents (four political parties: NRM, FDC, DP \&UPC) at a particular time, using a questionnaire. The researcher used a research strategy to confirm, cross validate, and corroborate research findings (Tunarosa \& Glynn, 2017).

\subsection{Triangulation}

Mathison (1988) defines triangulation as a method that helps the researchers to increase the level of accuracy about the phenomenon (Jick, 1979). The motivation for choosing triangulation was because any single qualitative research strategy has its limitations and a combination of different strategies help to validate data.

\subsection{Study Area}

The Albertine Region is of relatively low density and served by several urban growth centers. Lake Albert is surrounded immediately by nine districts: Nebbi, Nwoya, Buliisa, Masindi, Hoima, Kibaale, Kyenjojo, Kabarole, and Ntoroko; of which the oil exploration activities are located within Hoima, Buliisa and Nwoya. The Albertine Region is widely recognized for its ecological and biodiversity importance, and is part of the larger East Africa Rift System which stretches from the northern end of Lake Albert to the southern end of Lake Tanganyika and traverses the countries Uganda, Rwanda, Burundi, Democratic Republic of Congo (DRC) and Tanzania. The study targeted Members of Parliament who belong to NRM, FDC, UPC and DP political parties and the purpose was to assess political parties' representation influence on public policy formulation in Uganda's nascent 
Analysis of Political Parties Representation in Parliament Influence Public Policy Formulation in Uganda's Nascent Hydrocarbon Industry

hydrocarbon industry. The study area as a sub-theme briefly captures the genesis of hydrocarbon industry in Uganda since 1925 (Bategeka et al., 2013).

\subsection{Population of the study}

The research targeted a population of 490 to guide the study from which a sample size of 218 was selected and included: Leaders of major political organizations (04), the Prime Minister, leader of Opposition, Minister of Energy and Mineral Development and Chairperson of Committee of Natural Resources, Members of NRM in Parliament (329), Members of DP in Parliament (15), Members of UPC party in Parliament (06), Scholars who have written extensively on politics and public policy in Uganda (09) as shown in table one (1).

\subsubsection{Determination of the Sample size}

The researcher selected a sample of 218 from 490 a target population from a cross-section of the population that fulfills the requirements enumerated by Zikmund (2003), the Yamane formula (1967) and use of proportions was adopted. Through the Slovene's formula, the target population was 490 comprising 218 respondents as shown in Table 1. Sample population of 218 from which two categories of respondents were identified to guide the study (Hanlon, (2011). A sample size of 218 was selected and was calculated using Slovene's formula as shown below.

Table1: Sample Size Distribution

\begin{tabular}{|l|l|l|}
\hline Selected category of target Population & $\begin{array}{l}\text { Population } \\
\left(\boldsymbol{N}_{\boldsymbol{i}}\right)\end{array}$ & $\begin{array}{l}\text { Sample } \\
\mathbf{n}_{\mathbf{i}}=\frac{\boldsymbol{N}_{\boldsymbol{i}}}{\boldsymbol{N}} * \boldsymbol{n}\end{array}$ \\
\hline Leaders of NRMO, FDC, UPC and DP political parties & 04 & 04 \\
\hline Leader of Government Business in Parliament & 01 & 01 \\
\hline Speaker of Parliament & 01 & 01 \\
\hline Leader of Opposition in parliament & 01 & 01 \\
\hline Members of NRM in Parliament & 329 & 146 \\
\hline Members of Central Executive Committee of NRM party & 29 & 13 \\
\hline Members of FDC party in Parliament & 35 & 15 \\
\hline National Executive committee members of FDC party & 29 & 13 \\
\hline Members of DP in Parliament & 15 & 07 \\
\hline National Executive committee members of DP party & 31 & 14 \\
\hline Members of UPC party in Parliament & 06 & 03 \\
\hline Scholars who have written extensively on politics and public policy in Uganda & 9 & 4 \\
\hline Total & N=490 & $n=218$ \\
\hline
\end{tabular}

Source: Researcher, 2016

From Table 1.1: the researcher considered a sample size of 218 respondents selected from a total population of 490 .

\subsection{Sampling Techniques}

\subsubsection{Purposive Sampling Technique}

The researcher used purposive sampling techniques to select the sample for qualitative data collection. According to Neuman (2013), most qualitative studies use purposive sampling because they focus on in-depth information as opposed to inferences and generalizations. This study applied purposive sampling also known as judgment sampling where respondents were selected according to criteria specified by the researcher as recommended by Amin (2005). Using inclusion criteria, leaders of four political parties were considered in this study that included; NRM, FDC, DP and UPC Members of Parliament. This method was used because of a large target sample, and to avoid bias. Data collection and analysis took place in alternating sequences.

\subsubsection{Simple Random Sampling Technique}

The researcher applied simple random sampling to determine the sample size from the population. The researcher selected four political parties out of 29 registered in Uganda. The researcher used both purposive and simple random sampling given their characteristics. DP and UPC were selected because based on their history in Uganda as old political parties formed before 1962, NRM was selected because it is currently in power and FDC was selected because it is the only vibrant opposition political party in Uganda. Different methods of measuring a party system's fragmentation were employed. Aurel \& Wolfgang (1998), cite different scholars to explain criteria followed to select 
political parties for a study. Chunga (2014) counts number of effective parties while using fractionalization index. According to Njoroge (2014), a party must satisfy two criteria in order to count as relevant. In the selected Members of Parliament, cluster sampling was employed.

\subsection{Data Collection Methods}

The researcher used survey, interview and documentary review as data collection methods to collect both primary and secondary data. Secondary data included: textbooks, journals, government reports, unpublished theses and Hansard. While primary data was captured from respondents using questionnaire and interview guides. The researcher used a closed questionnaire drawn to a 5 likert scale. Amin (2005) explains that a questionnaire is set of pre-formulated written questions where respondents record their answers, usually within rather closely defined alternatives. This study used interview method to collect data by directly questioning or talking to the respondents (Zohrabi, 2013). Standardization of questions was maintained to increase data reliability and replication as much as possible. Content thematic analysis of the information generated was presented through narrations and verbatim quotes of the interviewees and key respondents (Green, 2014). Data was analyzed by making explanations and summaries. Quantitative data were analyzed by using statistical tools to reduce the data, summarize them and make the most important facts and relationships apparent. Quantitative data from both the questionnaires and interviews were subjected to statistical analysis using the Statistical Package for Social Sciences (SPSS).

\subsection{Methods of Data Analysis}

Neuman (2013) noted that any of the qualitative and quantitative analytical procedures or their combination may be employed if, from the evidence of the data collected, the situation demands. After coding and theme identification, the data were interpreted through descriptive, analytical and interpretive approaches (Agresti, 2011).

\subsubsection{Qualitative Data Analysis}

Content thematic analysis of the information generated was presented through narrations and verbatim quotes of the interviewees and key respondents (Green, 2014). Data were analyzed by making explanations and summaries. For key respondents, interviews were held and responses were analyzed, tabulated and coded. A content analysis is a system for defining categories of information and coding the basic units of each category (Kothari, 2010).

\subsubsection{Quantitative Data Analysis}

Quantitative data analysis entailed categorizing and summarizing data in order to find answers to the research questions. Quantitative data were analyzed by using statistical tools to reduce the data, summarize them and make the most important facts and relationships apparent. Quantitative data from both the questionnaires and interviews were subjected to statistical analysis using the Statistical Package for Social Sciences (SPSS). Data were analyzed using the Statistical Package for Social Sciences (SPSS) software programme. Quantitative data generated using questionnaires were analyzed using descriptive and inferential statistics (Field, 2009). This programme was used because it would enable simultaneous testing of a large number of variables. The data were then presented using percentages and frequencies. The tables were used to facilitate report writing.

\section{RESULTS AND DISCUSSIONS}

The research question for this objective was: How does political party representation in Parliament influence public policy formulation in nascent hydrocarbon industry in Uganda? Lastly, the hypothesis: $\mathrm{H}_{0}$ : Political parties' representation in Parliament does not influence public policy formulation in nascent hydrocarbon industry in Uganda. The Research objective of the study sought to assess opinion of respondents about political parties' representation in Parliament and public policy formulation in hydrocarbon industry. Data were collected using questionnaires, interview guide and documentary review guide and analyzed from completed questionnaires by the respondents which revealed varied responses as presented in Table 2.0.

Table2: Opinion of respondents about political parties' representation in Parliament on public policy formulation in hydrocarbon industry

\begin{tabular}{|l|l|l|l|l|l|l|l|l|}
\hline Statement & SD & D & N & A & SA & Mean & SD & Comment \\
\hline $\begin{array}{l}\text { Parliament provides a platform in which meaningful } \\
\text { debates occur. }\end{array}$ & 0 & 0 & 0 & 81.3 & 18.7 & 4.19 & .391 & High \\
\hline
\end{tabular}


Analysis of Political Parties Representation in Parliament Influence Public Policy Formulation in Uganda's Nascent Hydrocarbon Industry

\begin{tabular}{|c|c|c|c|c|c|c|c|c|}
\hline $\begin{array}{l}\text { Political parties in Parliament contributes meaningfully } \\
\text { to policy debates }\end{array}$ & 0 & 0 & 0 & 72.5 & 27.5 & 4.27 & .447 & High \\
\hline $\begin{array}{l}\text { Political parties allow members to present Private } \\
\text { Members Bills in Parliament. }\end{array}$ & 0 & 0 & 0 & 80.8 & 19.2 & 4.19 & .395 & High \\
\hline $\begin{array}{l}\text { The Chief Whip allows all Members of the party to } \\
\text { debate in Parliament. }\end{array}$ & 0 & 0 & 0 & 74.6 & 25.4 & 4.25 & .425 & High \\
\hline $\begin{array}{l}\text { Political parties are consulted on what is to be included } \\
\text { on the order paper. }\end{array}$ & 0 & 24.9 & 4.7 & 68.4 & 2.1 & 3.48 & .890 & Moderate \\
\hline $\begin{array}{l}\text { The Speaker of Parliament gives enough time to } \\
\text { Members to present policy issues in Parliament. }\end{array}$ & 0 & 0 & 0 & 80.3 & 19.7 & 4.20 & .399 & High \\
\hline $\begin{array}{l}\text { In Ugandan, by the time policy issues are brought to } \\
\text { parliament, policy positions are already set, partisan } \\
\text { lines drawn and policy outcomes determined. }\end{array}$ & 0 & .5 & 0 & 93.3 & 6.2 & 4.05 & .284 & High \\
\hline $\begin{array}{l}\text { Members of Parliament who sit on government side } \\
\text { favour policy making. }\end{array}$ & 0 & .5 & 0 & 84.5 & 15.0 & 4.14 & .390 & High \\
\hline $\begin{array}{l}\text { Members of Parliament who sit on Opposition side } \\
\text { favour policy scrutiny. }\end{array}$ & 0 & 5.2 & 1.6 & 79.3 & 14.0 & 4.02 & .603 & High \\
\hline $\begin{array}{l}\text { Ugandan Parliament has centralized agenda setting and } \\
\text { decision making. }\end{array}$ & 0 & 3.1 & 6.2 & 69.4 & 21.2 & 4.09 & .627 & High \\
\hline $\begin{array}{l}\text { Parliament preserves a certain distance or independence } \\
\text { to hold government accountable. }\end{array}$ & 0 & 0 & 0 & 71.0 & 29.0 & 4.29 & .455 & High \\
\hline $\begin{array}{l}\text { Parliament can simply ask the government for } \\
\text { information. }\end{array}$ & 0 & .5 & 0 & 81.3 & 18.1 & 4.17 & .417 & High \\
\hline $\begin{array}{l}\text { Parliament can ask the government for public } \\
\text { clarification of policy. }\end{array}$ & 0 & 0 & 0 & 73.1 & 26.9 & 4.27 & .445 & High \\
\hline $\begin{array}{l}\text { Parliament can obtain information from sources outside } \\
\text { the government. }\end{array}$ & 0 & 0 & 0 & 74.1 & 25.9 & 4.26 & .439 & High \\
\hline $\begin{array}{l}\text { Parliament can express its views to the government and } \\
\text { the public. }\end{array}$ & 0 & 0 & 0 & 76.7 & 23.3 & 4.23 & .424 & High \\
\hline Average Mean & & & & & & 4.14 & 0.469 & High \\
\hline
\end{tabular}

Source: Research Findings, (2017).

\subsection{Political Parties' Representation and Public Policy Formulation}

Table 2.0 shows the respondents' reactions to the first sub-construct on whether Parliament provides a platform in which meaningful policy debates occur. The findings revealed that $81.3 \%$ of the respondents agreed, while $18.7 \%$ strongly agreed. The calculated Mean $(\mu=4.19, S D=.319)$ implying that Parliament providing a platform in which meaningful policy debates occur was high in Uganda.

Brouard et al., (2018) argue that political organizations always work to influence public policy. Political party leaders quickly move to address policy issues that arise to capture public attention. Political parties always mobilize resources to push for policy change. Dominant ruling political parties and winner-take-all approaches to politics can also leave opposition groups so marginalized that their basic survival is at stake and policy formulation appears a luxury. It has been observed that political parties tend to influence policy change through elections.

Heinze (2017) elaborates that political parties adopt strategies that will help them grow strong to challenge for political power. Political strategies like: aggressive members' recruitment, formation of functional party structures, fundraising, massive members' political education, fielding of party candidates at all levels during elections. The party should as well work on effective communication among party structures. Caucusing should be one of the main party activities for policy debate and decision making.

Dalton (1985) political parties' representation is a cardinal role for any functioning democracy. Findings revealed that the effect of political party representation on public policy formulation in Uganda's nascent hydrocarbon industry was $14.2 \%$. These findings were in tune with previous studies as discussed in this sub-section. Llanto (2007) explains that in parliamentary democracy, political parties help to promote fair representation and effective participation in Parliament through regular elections. The electoral system allows for a single member constituency representation with a single majority of votes into the national assembly. The parliamentary representatives play an essential part in policy development in multiparty democracies. Members of Parliament present citizens' views in 
Analysis of Political Parties Representation in Parliament Influence Public Policy Formulation in Uganda's Nascent Hydrocarbon Industry

Parliament are involved in policy debates, policy, and scrutiny and policy adoption (Adar et al., 2008).

Tsekpo \& Hudson (2009) explain that parliament conducts legislative work through Committees and general functions of political parties include: policy debate and discussions. Magstadt (2003) explains that the party must appeal to various voter interests while reconciling and forging them into a workable majority. Even if a party has no hope of gaining a majority following, its influence and legislative strength usually depend on the size and distribution of its vote total, which in turn reflects its success in attracting voters across a relatively wide spectrum.

According to Maiyo (2010), in representative democracy, political parties are vital institutions that present policy demands to parliament on behalf of the citizens. Parliamentary democracy requires political parties through their members to participate in public policy formulation. Political parties influence policy process as non state actors.

These results are in tune with Maseng (2014) which revealed that the institution of parliament is paramount in democratic governance. Citizen sovereignty is exercised through free and regular elections where people elect their representatives to Parliament. Parliamentary democracy is, therefore, people power and policies initiated and debated in Parliament emanate from the concerns of the citizens. Boggild \& Pedersen (2018) contend that the Members of Parliament are expected to provide feedback to the citizens through defined and established mechanisms like meetings, and use of the media. The citizens are given chance to present their views through their representatives to Parliament. Members of Parliament could use the generated views from public meetings and present them as policy concerns in parliament. However, what is witnessed in Uganda is limited interaction with citizens who send political Assistants to represent them during social gatherings and nothing substantial is discussed.

Müller (2000) argues that limited number of opposition members in Parliament presents weaken negotiation and dialogue during public policy process. Opposition political parties in Uganda have minority seats in Parliament with FDC having 36 Members of Parliament, DP has 15 and UPC has 6 Members of Parliament compared to the ruling party NRM which has 293 Members of Parliament (Uganda Election Commission Report, 2016). The increasing number of Independents in the three national elections in Parliament (2006) were 33; (2011) were 45; and (2016) are 66 and this continuously complicates politics of policy making in Parliament and existence of political institutions (Gibb, 2016).

\subsection{Parliament and Policy Debate in Parliament}

Table 2.0 reveals that respondents' views on the second item on whether Political parties in Parliament contribute meaningfully to policy debates were as follows: The findings revealed that $72.5 \%$ of the respondents agreed, while $27.5 \%$ strongly agreed. The calculated Mean $(\mu=4.27, S D=$ .447) implying that political parties in parliament contribute meaningfully to policy debates was high. This indicates that political parties are given opportunity to contribute to meaningful debates in either plenary or Committees of Parliament in Uganda.

Chungong (2017) argues that parliament is a crucial institution in public policy-making globally. The institution of parliament plays an important role and, therefore, requires Members of Parliament to understand governance issues. Chunga (2014) contends that in many developing democracies, parliaments are weak, ineffective and marginalized. There is need to effectiveness build the capacity of parliaments through institutional development, which should target parliamentary staff, and Committees of parliament to improve the representative role of parliament.

Christova (1999) argues that the parliament plays a vital role in the life of a nation. It perform three main functions which include: make new laws, change existing laws and repeal laws which are no longer needed; represent and present the views and wishes of the public in policy making processes and finally, oversee the activities of the Executive so that the government remains accountable to the people. Draman (2012) explains that to achieve good governance in any democracy, a strong and effective parliament is required to prevail over political parties to practice mature and decent politics. This is possible because parliament plays a crucial role in gauging, collating and presenting the views and needs of the people, articulating their expectations and aspirations in determining the national development agenda. Parliament through its oversight role helps to identify problems and policy 
Analysis of Political Parties Representation in Parliament Influence Public Policy Formulation in Uganda's Nascent Hydrocarbon Industry

challenges that require attention and assists in overcoming bureaucratic inertia (Bräuninger et al., 2017).

The Parliament of the Republic of Uganda is the national legislative body which debates and passes laws/legislation through which the institutions of government endeavor to guide the country's progress. The Parliament of Uganda derives its mandate from Chapter Six of the Constitution of Uganda. Specifically, Article 77 (1) of the Constitution states that, "There shall be a Parliament of Uganda." The functions of the Parliament of Uganda include: to pass laws; to scrutinize Government policy and administration. Parliament is also mandated to vet the appointment of persons nominated by the President under the Constitution or any other enactment (Abola, 2014).

Scholars like Davis et al., (2016) argue that the Members of Parliament represent the public by articulating citizen preferences in Parliament. This also involves enacting appropriate legislations. The representative and law-making role of parliament co-exist in an uneasy but necessary relationship among political parties in parliament. The law-making function requires political parties to reconcile their political parties' differences once presented on the floor of Parliament. Evrard (2012) explains that the Executive through parliamentary caucusing and lobby groups should reconcile with opposition political parties on matters considered more pressing and contentious to avoid political standoff in Parliament. This can be done behind curtains through political leadership of the Speaker, Leader of Government Business, and Leader of Opposition in Parliament, Opposition Chief Whip and Government Chief Whip. This would necessitate the Speaker convening a special session to reconcile political conflicts between the Executive branch and other actors in the policy process in Parliament (Saiegh, 2005).

Franchino \& Hyland (2009) argue that in developing democracies, there is an overlap of roles between the legislature and executive branches of government. According to Russell et al., (2017), the Executive initiates policies proposals to parliament for debate, scrutiny and final approval. Parliament listens to policy proposals tendered in by different stakeholders during agenda setting. Parliament through Members of Parliament identify policy problems as policy issue for discussion.

From the second item on whether political parties in Parliament contribute meaningfully to policy debates, the findings revealed that $72.5 \%$ of the respondents agreed, while $27.5 \%$ strongly agreed. The findings are also supported by Jans \& Piedrafita (2009) who opine that Parliament is a critical institution that champions policy formulation process. The institution of parliament serves as a policy platform (Anderson \& Guillory, 1997). Parliament has a cardinal role to draft policies and laws that guide the management a strong Parliament guarantee quality policies for the country (Moore \& Thomas, 1991).

Parliament is the national legislature deriving its mandate from the Constitution of the land. It is composed of elected and appointed Members of Parliament depending on constitutional provisions including their term of office. The Members of Parliament represent gazetted. Parliament performs basic functions that include: representation, lawmaking, and oversight functions (Zalewska \& Gstrein, 2013).

Parliament is mandated to enact laws by subjecting public policy issues in form of private members bills. When bills are introduced in the house by either a Minister or Member of Parliament in his/her private capacity, they then go through a number of stages as laid down in the Parliamentary Rule of Procedures (Raunio, 2009).

Goldsworthy (2012) argues that parliaments and parties offer development programmes a way into almost every area of public policy. When working effectively, they can be an influential ally across a broad spectrum of objectives. They provide valuable routes to social, political and economic development, and provide forum for peaceful political debate. Greg \& Shoot (2012) assert that parliaments provide the means for elected representatives from across the political spectrum to scrutinise executive decisions and monitor public spending. They play a role in law making ranging from drafting legislation to scrutinizing laws drafted by the executive. Parliaments and political parties create opportunities for citizens to influence government decisions (Bräuninger et al., 2017).

Harrison (2014) argues that parliaments offer development programmes a way into almost every area of public policy. Political parties in Parliament influence public policy across a wide spectrum of objectives. Political parties and parliaments provide policies that guide government in provision of social, political and economic development through political debate. Parliament provide a platform where elected Members of Parliament from all political parties to scrutinise Executive decisions and monitor public spending. Holzhacker (2002) explains that parliament plays an important role in law making. Parliament provides a forum for policy and budgetary scrutiny in areas of economic and 
social reform. Parliaments are critical institutions that create opportunities for citizens to influence government decisions.

From the first sub-construct on whether 'Parliament provides a platform in which meaningful debates occur', results revealed that $81.3 \%$ of respondents agreed. These findings are in tandem with Yamamoto (2007) who referred to parliament as the legislative institution of government responsible for making laws, approving policies and overseeing the administration of public policy which are in tandem with public needs. Parliament is also charged with the responsibility of reviewing reports from Executive and public Agencies (Myers \& Mohammed, 2012). The key functions of parliamentary oversight include: detecting fraud and ensuring that adopted policies address the needs of the people and promoting transparency as a key principle of good governance (Mbete, 2016). The parliamentary oversight role is, therefore, intended to ensure that government delivers on the approved laws and policies approved by parliament.

\subsection{Political Parties' Consultation and Politics of Policy Making in Parliament}

Findings on whether political parties are being consulted on what is to be included on the order paper, the findings revealed that $68.4 \%$ of the respondents agreed, $2.1 \%$ strongly agreed, $4.7 \%$ were undecided while $24.9 \%$ disagreed. These results are in tune with Magee (2001) who argue that the policy process at agenda setting is the function of the executive. At agenda setting stage, key questions as this one are asked: what are the main policy issues and why should they be included on the agenda. The government in power would always have an upper hand in parliament to influence the policy direction to suit its political interests.

Consultation promotes popular stakeholders participation in policy making. Stakeholder consultation is a critical process in policy making because government captures issues that could have been ignored or omitted but are paramount in policy development. Stakeholders consultation promote good governance and rule of law (Morison, 2017).

Levy (2009) argues that institutional politics remains critical to policy process in any democracy. The link between politics and development is associated good policies initiated by political parties and passed by parliaments. Daley (2014) explains that political parties capture public needs that are translated into policy choices and policy actions by government. The contribution of political parties in policy process has significant effect on policy development.

Heidar \& Karlsen (2018) contend that political organizations generate policy issue that are specific to the needs of the people. Policy needs range from local to national levels that will need legislative mandate of parliament. Gromet et al., (2013) argue that political actions are always guided by party ideology. Parties communicate authoritative messages in form of policy actions. However, it was observed that in several cases, the results were weak.

Leighninger (2014) explains that citizens present policy demands in form of inputs from the environment. Jaakkola (2015) asserts that the civil society organizations are paramount in creating awareness on issues of representation and decision making in a modern democracy. Political demands are the main bargaining point during civic meetings to influence political decisions. Civic meetings bring political organizations, government and citizens together to arrive at consensus on issues that affect the public.

Mulyanyuma (2016) argues that many policies fail because of many factors which include: lack of technical expertise, regime change, limited funding, donor influence, complexity in policy implementation. Policy formulation requires competent and experienced personnel to analyze different policy alternatives to arrive at the best option. Regime change is another factor that affects policy process. New governments tend to abandon policies of previous governments.

Scholars like Hix \& Noury (2016) assert that politics of policy making in parliamentary or congressional involves voting on particular policy proposal and mobilizing for support among Members of Parliament. Political organization will always try to lobby for support for a particular policy to succeed or fail. Party leaders will opt for caucusing and manipulation as strategies to influence the voting pattern in parliament.

Negri (2017) argues that coalitions and party alliances are important in policy process. Minority parties choose to form alliances to assert policy relevancy. Ideology of parties determines coalitions and policy direction. Keefer (2015) contends that coalitions will be sustainable if divergent party 
ideologies and personality issues are addressed. The ideological Left-Right scale affects policies to be adopted especially on welfare programmes. Information sharing among coalition parties becomes eminent for effective alliances. It is observed that the ruling parties tend to adopt policies that address their ideological thinking. NRM political organization considers hydrocarbon discoveries as its project and policies adopted favour its existence and party sustainability. Most of the vital information about the hydrocarbon industry is still limited to party leaders.

A Member of Parliament from the Committee of Natural Resources raised a concern of how the oil and gas resources are managed and during an interview cited provisions in law as follows:

Section 10 and 13 of the Public Finance Management Act, (2015) requires transparency on the oil proceeds but these sections are not being followed by government (Field data, 2018).

In many democracies, main political parties have established political party structures. The relationship between different party structures helps in political party institution building, longevity and relevancy in political spectrum. Different political leaders emerge to take leadership positions after going through political party education, mentorship and ideological orientation. Political education in party politics enhances nation building of the country and transparency and accountability is paramount to political development (Giannetti \& Laver, 2008). Another key informant who is also a member on the Parliamentary Committee of Natural Resources during the interview said:

We want the Government to publish information regarding the status of the oil revenue as provided for in Section 61 (2) of the Public Finance Management Act, (2015) that requires that the citizens can know about oil and gas transaction in Uganda (Field data, 2018).

This implies that public policy formulation in Uganda has remained a government function and political parties only endorse what NRM has developed and presented to parliament. A Key informant in the office of the Speaker of Parliament noted:

There would be no need to pressurize government to provide information about oil and gas sector in Uganda because that is what the law requires. We also advised government to join the Extractive Industries Transparency Initiative (EITI) on oil but they have not done so (Field data, 2018).

From this discussion, it is observed that Parliamentary resolutions on oil and gas sector in Uganda take long to be implemented by Government. The hydrocarbon laws are adequate but hardly followed and adhered to as noted by the Speaker of Parliament in her submission. Another key informant representing Ministry of Energy and Mineral Development in Uganda during documentary review referred to one of the reports presented to Cabinet and Parliament categorized as public information available to Members of Parliament and general public concerning oil and gas sector:

NRM party adheres to principles of good governance and shares information on oil and gas sector with the public. NRM party has registered achievements in the hydrocarbon industry which include: discovery of 21 oil wells that have 6.5 billion barrels of oil and 500 billion cubic feet of gas; a total of 106 exploration and appraisal wells have been drilled out of which 120 had hydrocarbons, registering one of the highest drilling success rates in the industry; a total of 17 of the wells said to have oil have been taken up by investors for development; appraisal of 16 wells has been concluded; feasibility studies for the oil refinery and an export pipeline have been completed; the Government has developed a National Content Policy and Implementation Strategy and Plan covering tenets of employment for Ugandans; procurement of locally produced or available goods and services; national enterprise development; enhanced vocational and higher education and training; and measurement and monitoring of national content. Three international oil companies were licensed to undertake exploration of oil and gas in the country, namely: Tullow, CNOOC and Total. These companies all hold equal equity participation in the existing contract areas. The NRM Government has pledged to build a refinery with capacity to produce 60,000 barrels per day in two phases (Field data, 2018). 
Analysis of Political Parties Representation in Parliament Influence Public Policy Formulation in Uganda's Nascent Hydrocarbon Industry

However, no mention is made on how these achievements were shared in NRM party delegates' conference, Central Executive Committee (CEC), National Executive Committee (NEC), Parliamentary Caucuses, NRM Kyankwanzi retreats or with other political parties in Inter Party Organization for Dialogue meetings. It has also been observed that the information provided by Ministry of Energy and Mineral Development is thin and limited in scope and, therefore, not detailed enough to inform the public on Uganda's nascent hydrocarbon industry. This presupposes that Ministry of Energy and Mineral Development is still secretive and not ready to share information on the management of oil and gas resources unless demands are made by different stakeholders. Izama \& Okao (2011) argue that even when NRM party had made tremendous contribution in developing oil and gas policies, the hydrocarbon industry has lacked the fundamental elements of good governance in Uganda.

\subsection{Political Parties and Private Member's Bills in Parliament}

The findings from the third sub-construct on whether political parties allow members to present Private Members Bills in Parliament had similar responses. The findings revealed that $80.8 \%$ of the respondents agreed, while $19.2 \%$ strongly agreed. The calculated Mean $(\mu=4.19, S D=.395)$ implying that political parties allow their members to present Private Members bills in Parliament is high. The Standard Deviation indicates that there was no variation in responses on this item. Opinions on gender were computed using Pearson Chi - Square analysis $(\chi 2=5.869, \mathrm{df}=1, P=0.015)$. The theoretical value from the Pearson Chi - Square table at 5\% level of significance and $\mathrm{df}=1$ is 3.84 . Since the calculated value is greater than theoretical value, it implies that our calculated value lies in the reject region. The region of rejection is all $\chi^{2}$ values of $\chi^{2}=5.869$ or more. We therefore, reject $\mathrm{H}_{0}$ represented by (i) accept $\mathrm{H}_{1}$ and we say that political parties allow members to present Private Members Bills in Parliament had a significant relationship with Gender of respondents. Gender is, therefore, a key determinant in policy debates in Uganda's parliament.

The third sub-construct was whether 'political parties allow members to present Private Members Bills in Parliament'. The findings revealed that $80.8 \%$ of the respondents agreed, while $19.2 \%$ strongly agreed. Levy (2009) explains that parliament plays a critical role in scrutiny of bills if their capacity is built in terms of political party members' trainings. The research findings agree with these findings based on the fact that it is easy for those who have served as Members of Parliament for more terms because they understand the integrity of policy making better than new members. In Uganda, the majority of members in the tenth Parliament are new and this could explain variation in responses by respondent.

House of Commons Information Office Report, (2010) revealed that Private Members' Bills attract less attention in Parliament than Bills presented by Cabinet Ministers. Statistics showed that out 542 Private Members' Bills introduced in Parliament in the United Kingdom, only thirty two were debated in Parliament in 1997. The obstacles that affect Private Members Bills' progress include: absence of defined end time for debates; Members who do not support the Private Members' Bills would always frustrate them demanding for procedural details; it is always hard to convene a Parliamentary sitting to discuss the Private Members' Bill; Private Members' Bills receive a lot of interruption by Members opposing the Bill; and finally, Private Members' Bills always fail to attract support from Members who might have failed to muster the policy content and objective of the Bill. This, therefore, explains the variation in response by respondents on the third sub-construct of whether political parties allow members to present Private Members' Bills in Parliament.

The introduction of the Bill in Uganda's Parliament is according to Rules of Procedure. The Bill goes through the processes of Parliament necessary for passing a Bill. The Rules of Procedure Rule 114 provides that every Bill shall be read three times prior to its being passed. The processes are prescribed by the Rules from Parts XVIII - XXI as follows: The first Reading of the Bill requires official introduction of the Bill in Parliament which is then referred to the relevant Sessional Committee of Parliament for further scrutiny and discussion. At this stage, the relevant committee will normally invite the relevant Minister to introduce the Bill and may invite other stakeholders to state their views on the provisions of the Bill and the committee responsible may even sometimes hold hearings for the purpose. The committee then submits a Report to the Sessional Committee. It is a requirement by the committee to the plenary of Parliament and at the same time. Parliament will consider the Bill at Second Reading for a debate on the principles and policies of the Bill and not on its details. According to rule 119(5) of the Rules (subject to the Rules) the Second Reading of the Bill shall not be taken earlier than the fourteenth day after publication of the Bill in the Gazette, unless the 
Analysis of Political Parties Representation in Parliament Influence Public Policy Formulation in Uganda's Nascent Hydrocarbon Industry

sub-rule is formally suspended for the purpose. The Bill is submitted to the Committee of the Whole House Stage: This is the stage of the Bill at which Parliament deals with the provisions of the Bill, clause by clause and all proposed amendments to the Bill are taken note of. The Committee Stage is regulated by Part XX of the Rules (rules 120 - 124) of the Rules of Procedure and the Speaker sits considers amendments to the Bill (rule 122(1) (Rules of Procedure of the Parliament of Uganda, 2006).

Private Member's Bill is provided for under Article 94(4) of the 1995 Constitution of the Republic of Uganda. The 1995 Constitution of Uganda also provides for the initiation of Bills by private members of Parliament. Article 94 (4) provides that the rules of procedure of Parliament shall include the following provisions: "(b) a Member of Parliament has the right to move a Private Member's Bill; (c) the member moving the Private Member's Bill shall be afforded reasonable assistance by the Department of Government whose area of operation is affected by the Bill; and (d) the Attorney General shall afford the member of Parliament professional assistance in the drafting of the Bill." Rule 110 of Rules of Procedure provides for the Private Member's Bill and rule 111 of the Rules provides for the following procedure in respect of a Private Member's Bill (Manual on the Legislative Process in Uganda, 2014).

\subsection{The Role of Chief Whips and Public Policy Debates in Parliament}

In Table 2.0, the fourth sub-construct on whether the Chief Whip allows all Members of the party to debate in Parliament, the responses were similar. The findings revealed that $74.6 \%$ of the respondents agreed, while $25.4 \%$ strongly agreed. The calculated Mean $(\mu=4.25, S D=.425)$ implying that the Chief Whip allows all Members of the party to debate in Parliament was satisfactory. The Standard Deviation implies that there was no much variation in the respondents' views on this sub-construct.

As it can be shown from Table 2.0, considering the issue of political parties being consulted on what is to be included on the Order Paper, the findings revealed varied opinions. The findings revealed that $68.4 \%$ of the respondents agreed, $2.1 \%$ strongly agreed, $4.7 \%$ were undecided while $24.9 \%$ disagreed. The calculated Mean $(\mu=3.48, S D=.890)$ implying that on the issue of whether political parties are consulted on what is to be included on the Order Paper was moderate.

The term 'whip' has origin in the British parliament which meant the person who kept the House in order. The whips remind party members to attend party members, plenary and committee meetings (Walpole \& Kelly, 2008). The opposition Chief Whips as in Britain provides the same functions in Canada. The Chief Whip communicates to party members' policy position in parliament (Agozino, 2015). The Chief Whip organizes the business of the House, liaise with the Opposition parties, and to keep members from their party informed and organized. Chief whips serving to achieve party cohesion in parliament (Cowley \& Stuart, 2015).

In Uganda's the roles of Whips are provided for in the Rules of Procedure of Parliament The Government Chief Whip is appointed by the Government from among Members of Parliament representing the ruling party whose role and functions is to ensure due attendance, participation in proceedings and voting in Parliament of Members of the ruling party. The Government Chief Whip also performs such other functions as provided under sub-rule (10) of this rule. The Chief Opposition Whip is appointed by the party in Opposition to the Government having the greatest numerical strength among the Opposition parties in Parliament whose role and functions is to ensure due attendance, participation in proceedings and voting in Parliament of Members of the Party in Opposition in Parliament. The Chief Opposition Whip also performs such other functions as provided under sub-rule (10) of this rule. Other functions of the Government Chief Whip, Opposition Chief Whip and Party Whip include: organizing party business; keeping Members informed of business; supplying lists of Members to serve on Standing and Sessional Committees; co-operating with Whips in putting into effect and coordinating agreed Parliamentary business; acting as intermediaries between leaders and other party Members; arranging representations of party Members on official Parliamentary delegations; and acting as tellers during divisions (Rules of Procedure of the Parliament of Uganda, 2006).

Findings on fourth sub-construct on whether 'the Chief Whip allows all Members of the party to debate in Parliament' the findings revealed that $74.6 \%$ of the respondents agreed, while $25.4 \%$ strongly agreed. The research findings are in tune with Russell \& Paun (2006) whose study on managing Parliament better in the United Kingdom revealed that Parliamentary Business and agenda setting are agreed upon between the Chief Whip and two main parties in Parliament. Allocation of 
time and appointment of various Committees of Parliament is the mandate of the Chief Whip. The Chief Whip is also mandated to decide on what should be included on the agenda during Parliamentary Business Committee through informal or formal negotiations (Kwagala - Igaga, 2012). The provisions in the standing order 14 allocate government more time in Parliament in the House of Commons. Since Uganda was a British colony that adopted the British legal system, there is little difference in the structuring of parliamentary laws and this explains a small variation in responses from respondents in this study. The Speaker of Parliament is the presiding officer of Parliament in Uganda. During plenary, the Speaker gives opportunity to every Member of Parliament to speak (Flinders, 2006).

\subsection{The Role of the Speaker and Public Policy Debates in Parliament}

As regards the Speaker of Parliament giving enough time to Members of Parliament to present policy issues in Parliament respondents gave similar opinions. The findings revealed that $80.3 \%$ of the respondents agreed, while $19.7 \%$ strongly agreed. The calculated Mean $(\mu=4.20, S D=.399)$ implying that the Speaker of Parliament gives enough time to Members of Parliament to present policy issues in Parliament was high. The Standard Deviation shows that there was no much variation in the way respondents answered this item.

On the issue of whether "by the time policy issues are brought to Parliament, policy positions are already set, partisan lines drawn and policy outcomes determined," respondents gave similar opinions. The findings revealed that $93.3 \%$ of the respondents agreed, while $6.2 \%$ strongly agreed. The calculated Mean $(\mu=4.05, S D=.284)$ implying that by the time policy issues are brought to Parliament, policy positions are already set, partisan lines drawn and policy outcomes determined was high. The Standard Deviation shows that there was no much variation in the way respondents answered this item. Scholars like Tripp (2004) and Negri (2017)explain that the Speaker chairs policy debates in Parliament and he/she is the chief officer and highest authority in Parliament. Heitshusen (2017) argues that the Speaker keeps order and gives permission to members in the House to deliberate. The Speaker over rules on matters of contention and also presides over voting in case the issue under discussion demands so.

The Parliament of Uganda is headed by the Speaker of Parliament, assisted by the Deputy Speaker. It conducts its business in both plenary and Committees of Parliament. Under Article 90 (1) of the Constitution, Parliament is empowered to "appoint committees necessary for the efficient discharge of its functions". At present, there are Sessional, Standing and Ad hoc Committees of Parliament. Their roles and functions are described under the rules of procedure of the Parliament of Uganda. On the administrative side of parliament, business is conducted with the support of the Parliamentary Service supervised by the Parliamentary Commission, established by the Constitution under article 87A. The administration of parliament is governed by the Administration of Parliament Act of 1997 as amended in 2006 (Doro \& Kufakurinani, 2018).

Russell \& Cowley (2016) explain that in parliamentary System, Members of Parliament elect among themselves the Speakers and Deputy Speaker of Parliament to preside over the functions of the House of Commons. The Speaker of Parliament has to be neutral and not to belong to any political organization. IIie (2014) explains that the Speaker presides over parliament during plenary and exercises completely unbiased policy position and must not show favouritism towards any political party. However, in Uganda, the Speaker and Deputy Speaker continue to support and subscribe to NRM party position. It has been observed that during NRM party retreat at Igongo Cultural Center in Mbarara on December 23, 2018, the ruling NRM top organ, the Central Executive Committee (CEC) that included the Chairman of the political party President, Y.K Museveni; the Prime Minister, Dr. Ruhakana Rugunda; the Speaker of Parliament, Rebecca Kadaga; and the NRM Secretary General, Justine Kasule Lumumba, were some of the members who attended the meeting which discussed the 2021 general election roadmap for NRM party among other policy issues. The principle of impartiality and unfairness the Speaker of Parliament is expected to exercise is highly questionable. Mutabazi (2010) argues that the Executive Branch of Government and the Presidency has great influence in Uganda's Parliament. The Speaker and Deputy Speaker of Parliament are members of NRM political party and they have never resigned their positions as Members of Parliament representing their constituencies. Kelso (2016) argue that the rules of procedure govern the plenary. Each motion will receive equal attention during policy debate. 
Analysis of Political Parties Representation in Parliament Influence Public Policy Formulation in Uganda's Nascent Hydrocarbon Industry

As regards the Speaker of Parliament giving enough time to Members of Parliament to present policy issues in Parliament, the results revealed that $80.3 \%$ of the respondents agreed, while $19.7 \%$ strongly agreed. This is in agreement with Zwibel's, (2016) research studies conducted in Canada that revealed that in parliamentary democracy, government controls the legislative agenda. The party with majority seats in Parliament will ultimately influence policy debates and decisions. Studies conducted by Russell \& Cowley, (1994) in the United Kingdom revealed that Westminster has significant influence on public policy formulation. Whereas these studies (Zwibel, 2016; Russell \& Cowley, 2015) were done in developed countries, they seem to agree with what is currently happening in Uganda. Curini et al., (2018) argue that governments will hurry of passage of cabinet Bills if they are threaten to lose legitimacy. It has observed that in Uganda, controversial Bills that favour government policy position are passed hurriedly under strict state surveillance and tough NRM Parliamentary Caucus rules.

\subsection{The Ruling Party and Public Policy Debates in Parliament}

Regarding the eighth item on whether Members of Parliament who sit on government side favour policy making, respondents gave similar opinions. The study revealed that $84.5 \%$ of the respondents agreed, while $15.0 \%$ strongly agreed. The calculated Mean $(\mu=4.14, S D=.390)$ implying that Members of Parliament who sit on government side favour policy making was high. The Standard Deviation shows that there was no much variation in the way respondents answered this item. The opinions of respondents by gender were computed using Pearson Chi - Square analysis $\left(\chi^{2}=6.872\right.$, $\mathrm{df}=2, \mathrm{P}=0.032$ ). The theoretical value from the Pearson $\mathrm{Chi}-$ Square table at $5 \%$ level of significance and $\mathrm{df}=2$ is 5.99. Since the calculated value is greater than theoretical value, it implies that our calculated value lies in the reject region. The region of rejection is all $\chi^{2}$ values of $\chi^{2}=6.872$ or more. We therefore, reject $\mathrm{H}_{0}$ represented by (i); accept $\mathrm{H}_{1}$ and we say that Members of Parliament who sit on government side in parliament favour policy making, had a significant relationship with gender of respondents and, therefore, influence public policy formulation in Uganda's nascent hydrocarbon industry.

As regards Members of Parliament who sit on Opposition side favouring policy scrutiny, respondents gave similar views. The findings revealed that $79.3 \%$ of the respondents agreed, while $14.0 \%$ strongly agreed. The calculated Mean $(\mu=4.02, S D=.603)$ implying that Members of Parliament who sit on Opposition side favouring policy scrutiny was high. The Standard Deviation shows that there was no much variation in the way respondents answered this item. The opinions given by respondents from different political parties were computed using Pearson Chi - Square analysis $(\chi 2=38.120, \mathrm{df}=9$, $\mathrm{P}=0.000$ ). The theoretical value from the Pearson Chi - Square table at 5\% level of significance and $\mathrm{df}=9$ is 16.92 . Since the calculated value is greater than theoretical value, it implies that our calculated value lies in the reject region. The region of rejection is all $\chi^{2}$ values of $\chi^{2}=38.120$ or more. We therefore, reject $\mathrm{H}_{0}$ represented by (i); accept $\mathrm{H}_{1}$ and we say that Members of Parliament who sit on Opposition side in parliament favour policy scrutiny had a strong relationship with respondents' political parties.

Gutman et al., (1999) argue that political decision-making follow participatory approaches where citizens are involved. Oloka-Onyango (1992) explains that the NRM government has adopted participatory approaches to decision-making. The Electoral Commission of Uganda organizes regular periodic elections where citizens participate to elect their leaders at all levels of governance structures. The government of Uganda has also adopted the decentralization policy as an approach of good governance. However, the political environment does not favour opposition political parties to fairly compete in national elections and this affects the rights of citizens to make appropriate choices of their leaders as an approach to good governance and rule of law.

On the issue of whether Members of Parliament who sit on government side favouring policy making, study results revealed that $84.5 \%$ of the respondents agreed, while $15.0 \%$ strongly agreed. The results are consistent with studies done Olanya (2011) argues that National Resistance Movement party which has monopolized politics in Parliament to-date and in 2006 multiparty elections, had 211 seats in parliament; FDC had 38; DP 10; Uganda Peoples' Congress had 09; Justice Forum had 01; Conservative Party had 01 while Independents were 26. The NRM party has continued to dominate policy debates in Uganda's Parliament given the fact that since 2006 elections, it has majority seats in Parliament. Multiparty politics in Uganda has been characterized by uncertainties and the performance of Parliament greatly affected. 
Khisa (2017) argues that sustaining an authoritarian regime is a complex and costly endeavour. It often entails dissuading different social and political actors from challenging the status quo. In Uganda, the decisive factor has been maintaining the loyalty of the core ruling coalition through the simultaneous use of informal networks, patronage and coercion that combine to form a bulwark against a strong opposition coalition. It was Besigye dilemma in 2001/2006 and Mbabazi's in 2016 presidential elections. As a senior opposition leader remarked,

Being in opposition is very costly here. Your children become unemployable and you cannot do business. They have made being in opposition a very costly venture.

The costliness of opposition politics plays a prohibitive function. It compels many elites to either stay with the regime or retire into private life from where they can have access to state largesse through business dealings. Those who stay in opposition find that they cannot successfully do profitable private business.

Current understandings of regime survival in Uganda tend to overemphasise the role of 'semiauthoritarian' and 'neo-patrimonial' politics and neglect the extent to which the regime deploys alternative strategies of political rule that also involve 'soft' forms of power and formal elements of State-building. President Museveni deploys 'soft' power to deal with popular concerns, fears and carefully manages his political rivals. Meanwhile, some bureaucrats have effectiveness helped in securing legitimacy amongst both the voters through campaigning and voter manipulation. However, whilst this capacity to manage 'institutional multiplicity' has underpinned the regime's success in maintaining itself in power for over three decades, a closer understanding of how this balancing act is achieved helps expose the increasingly contradictory logics of regime survival, democratisation and state building in Uganda (Golooba-Mutebi \& Hickey, 2016).

According to Lo et al., (2014), party discipline is an important ingredient of strong party. Members of Parliament need to support their parties regardless of internal contradictions. Rebellions by party members weaken party legitimacy and threaten its development. The internal contradictions could be as the result of failure by the party to listen divergent members' views, ideological disorientation and lack of internal party democracy.

\subsection{Parliament and Policy Scrutiny}

Furthermore, Table 2.0 reveals that most respondents varied their opinion on the issue of whether Uganda Parliament has centralized agenda setting and decision making. The findings revealed that $21.2 \%$ strongly agreed, $69.4 \%$ agreed, $6.2 \%$ were neutral, and $3.1 \%$ disagreed. The calculated Mean $(\mu=4.09, S D=.627)$ implying that Uganda Parliament has centralized agenda setting and decision making was high. The opinions given by respondents from different political parties were computed using Pearson Chi - Square analysis $\left(\chi^{2}=59.059, \mathrm{df}=9, \mathrm{P}=0.000\right)$. The theoretical value from the Pearson Chi - Square table at 5\% level of significance and $\mathrm{df}=9$ is 16.92 . Since the calculated value is greater than theoretical value, it implies that our calculated value lies in the reject region. The region of rejection is all $\chi^{2}$ values of $\chi^{2}=59.059$ or more. We therefore, reject $\mathrm{H}_{0}$ represented by (i); accept $\mathrm{H}_{1}$ and we say that Uganda Parliament has centralized agenda setting and decision making had a strong relationship with respondents' political parties.

As regards the eleventh construct on whether Parliament preserves a certain distance or independence to hold government accountable, respondents provided similar opinions. The findings revealed that $71.0 \%$ of the respondents agreed, while $29.0 \%$ strongly agreed. The calculated Mean $(\mu=4.29, S D=$. 455) implying that on the issue of whether Parliament preserves a certain distance or independence to hold government accountable was high. The Standard Deviation shows that there was little variation in the way respondents responded to this item.

When it came to the issue of whether Parliament simply asks the government for information, respondents gave similar views. The findings revealed that $81.3 \%$ of the respondents agreed, while $18.3 \%$ strongly agreed. The calculated Mean $(\mu=4.17, S D=.417)$. All respondents agreed that Parliament simply asks the government for information and it is provided and the response rate was high. This information is provided as Ministerial Policy Statements, Reports to Committees of Parliament and Policy Briefs on implementation levels of government policies. The Standard Deviation shows that there was no variation in the responses on this particular issue. The opinion given by respondents from different political parties was computed using Pearson Chi - Square 
analysis $(\chi 2=20.317, \mathrm{df}=6, \mathrm{P}=0.002)$. The theoretical value from the Pearson Chi - Square table at $5 \%$ level of significance and $\mathrm{df}=6$ is 12.59 . Since the calculated value is greater than theoretical value, it implies that our calculated value lies in the reject region. The region of rejection is all $\chi^{2}$ values of $\chi 2=20.317$ or more. We therefore, reject $\mathrm{H}_{0}$ represented by (i); accept $\mathrm{H}_{1}$ and we say that on the issue of whether Parliament simply asks the government for information on hydrocarbon industry, the findings revealed a significant relationship with respondents' political parties.

As regards the issue of whether Parliament can ask the government for public clarification of policy, respondents gave similar views. Study results revealed that $73.1 \%$ of the respondents agreed, while $26.9 \%$ strongly agreed. The calculated Mean $(\mu=4.27, S D=.445)$. All respondents agreed that Parliament can ask the government for public clarification of policy issue and the response level was high. The Standard Deviation shows that there was no variation in the responses on this particular issue. Clarity in this case meant detailed explanation in form of a report by responsible Ministers or Government Official concerned to Committees of Parliament or during Plenary about an issue in contention and in this case, management of hydrocarbon industry.

Findings on issue of whether 'Members of Parliament, who sit on Opposition side favouring policy scrutiny', the results revealed varied views. The findings revealed that $79.3 \%$ of the respondents agreed, while $14.0 \%$ strongly agreed. These results are in tune with Flinders (2006) whose findings revealed that parliament and Executive are dominant institutions in the policy making process. The Executive asserts more powers and influence on Parliament to dictate the policy direction for particular programmes (Howlett et al., 2014).

Scholars like Eggers \& Spirling (2015) argue the shadow cabinet is an important institution of parliament vital in policy scrutiny. The opposition is an important political institution useful because it criticizes and it is presented as an alternative government. The opposition political party is also a shadow or alternative government. It has of would be Ministers, including a leader of Opposition in Parliament, shadow Cabinet, Chief Whips and its own party programme. If the opposition political party of the day can rarely defeat the government, then certainly modifies legislation by amendment and, through criticisms, weaken the confidence of the government and undermines its support in the country.

Despite the fact that opposition parties exist, they are peripherized and the ruling party enjoys dominance in policy making because of the majority seats it has in Parliament (Lee, 2013). It is, therefore, hard for opposition political parties to influence policy decisions in Parliament where they do not enjoy majority seats. This is true with Uganda, where NRM political party has majority seats and, therefore, dominates policy debates and decision making in Uganda Parliament. The politics of numbers of Parliament is dominant in both developing and developed democracies.

These results are in agreement with Levy (2009) whose research findings revealed that Committees of Parliament lack required legislative legal drafting skills to effectively prepare and debate private and government Bills. It was also revealed that Parliamentary scrutiny has also remained a big challenge to many Members of Parliament. The processes and procedures followed in assessing approved policies and programmes remain a challenge in many developing democracies. The study, therefore, suggests continuous trainings to build capacity of Members of Parliament.

These results are also in tandem with Mbete (2016) whose findings revealed that oversight and accountability are key functions of Parliament. Parliament through various Committees scrutinizes public expenditure and demands for accountability from government actions. The study reveals capacity gaps among Members of Parliament in the field of policy scrutiny and accountability in terms of qualifications and trainings. The majorities of Members of Parliament possess basic qualifications and do not have capacity to scrutinize and capture details from reports present by technocrats and simply rely on the few members who could be from the ruling party.

Interviews were conducted to validate quantitative data. It was revealed that some Members of Parliament are always absent during policy debates and scrutiny in Committees of Parliament and generally present total ignorance during plenary and policy adoption stage. One member of the Civil Society Organization described the $10^{\text {th }}$ Parliament as:

Uganda's tenth Parliament has 40-50 MPs who are competent, and effectively engage in parliamentary debates. The rest of the MPs are simply occupying political space, waiting to receive allowances, salary and probably participate in voting but have less to offer in terms of policy debates (Field Data, 2018). 
The findings are in tune with Russell \& Cowley (2016) who contend that parliamentary caucuses strengthening functionality of political organizations. Winetrobe (2000) explains that the Executive influence parliamentary policy debates on issues considered important to the ruling government. The Executive is mandated to present policy proposals/Bills to Parliament for scrutiny and approval. However, in many instances, the Executive-Parliamentary relations is always overlooked and policy debates in Parliament result into fights instead of negotiations and dialogue between opposition political parties and the ruling government. It has been observed that there is a reducing role of Parliament and government continue to assert its influence through its members. Adhered to the Doctrine of Separation of Powers is, therefore, mythical.

\subsection{Parliamentary Caucuses and Policy Debates in Parliament}

Findings on the issue of whether Uganda Parliament has centralized agenda setting and decision making revealed that $21.2 \%$ strongly agreed, $69.4 \%$ agreed, $6.2 \%$ were neutral, and $3.1 \%$ disagreed. A Key informant from the academic fraternity gave his views on whether political parties have influence on policy formulation said:

I think that policy making in Uganda is partially influenced by political parties in many ways which include: representation in parliament and members of parliament have a task to remain loyal to their party policy position. But the personality of President Museveni, State House and his Kyankwanzi meetings have more influence on public policy formulation than political parties. If one claims that NRM influences public policy formulation given the numerical strength in parliament, is wrong because NRM is President Yoweri Museveni and as a Chairman of the party, he simply directs on which policy to adopt or fail in parliament. This is not new in politics; the president in power will always influence policy direction to serve his/her political interests (Field data, 2017).

These results are in tandem with Chungong (2017) whose results revealed that the oversight function is a big challenge to a majority of Members of Parliament in developing democracies. Parliamentary oversight role is highly technical and require experienced and knowledgeable personnel unfortunately, few of the MPs have that capacity.

\subsection{Independence of Parliament and Public Policy Formulation}

As regards the fourteenth sub-construct on whether Parliament can obtain information from sources outside the government, respondents gave similar opinions. The findings revealed that $74.1 \%$ of the respondents agreed, while $25.9 \%$ strongly agreed. The calculated Mean $(\mu=4.26, S D=.439)$. All respondents agreed that Parliament can obtain information from sources outside the government which had a high response rate. It means that Parliament can cause an investigation on a particular issue if available information is not conclusive on a particular issue as its oversight role. The Standard Deviation shows that there was very little variation in the responses on this issue among respondents. Goldsworthy (2012) explains that the independence parliament is amplified in Professor Dicey's theory of 'continuing' sovereignty which states that there are no limits to the legislative competence of Parliament. Parliament has absolute sovereign power to take decisions on matters of national importance without any influence.

Results on whether Parliament preserves a certain distance or independence to hold government accountable. The findings revealed that $71.0 \%$ of the respondents agreed, while $29.0 \%$ strongly agreed. This confirms earlier studies by Bunn (2017) on parliamentary accountability. Sebastian (2005) contends that the independence of parliament guarantees objectivity during scrutiny of reports from Executive arm of government. The Public Accounts Committee of Parliament reviews all Ministries, Agency and Departmental reports on expenditure of public funds and corresponding services provided. Parliament, therefore, controls government actions through policy and financial scrutiny. Russell et al., (2017) argue that UK parliament is credible institution and its influence is significant felt globally where all institutions of the House are operational. Nogoibaeva (2014) are public policy formulation is an uphill task in many developing democracies. The role of Parliament in initiating public policy sometimes has overriding challenge in multiparty politics. Institutional willpower is a major contributory factor behind successful public policy formulation in both developed and developing economies. 
Scholars like Weeks (2016) argue that independents are emerging as a big challenge to existing political organizations globally. Schwarz \& Ladner (2009) explain that candidates choose to be neutral while campaigning for political leadership. Independents always emerge due to party disagreements on selection of suitable party candidates. The lack of internal party democracy forces some members to choose being moderate instead of being inclined to any registered political grouping. In other instances, independents lack defined political ideology or are in disagreement with party ideology and interests. The independents differ in political opinion and ideology with political parties and choose to remain not inclined to any party in parliament. Political parties work tirelessly to lure independents to their side through signing of memorandum of understanding.

Collord (2016) contends that the increasing number of Independents and stagnating number of opposition Members in parliament complicates politics of policy making in Uganda's Parliament. Enyedi (2016) argues that in Parliamentary democracy, party disciplined and cohesion is vital in promoting unity and internal party discipline. Gauja (2015) explains that party cohesion enhances accountability, participation and transparence as a gesture of good governance among politicians. However, of recent, party members have exhibited high indiscipline by party switching membership among parties. There is new trend where Members of Parliament change their party affiliation (Volpi, 2017).

Meanwhile, Hobolt \& Tilley (2016) argue that in the Euro zone, many voters have turned back to their former parties. The voters who were economically adversely affected by the economic crisis punish mainstream parties both in government and in opposition by voting for challenger parties. The findings revealed that the economic challenges have been addressed and reshaped the nature of political party competition. In Africa, the social and economic challenges have threatened the existence of traditional political parties. Similar views are shared by Namuyondo (2013) whose work revealed that African governments are maintained in office through control of vital institutions of the state.

Findings on the issue of whether Parliament simply asks the government for information revealed varied views. The finding revealed that $81.3 \%$ of the respondents agreed, while $18.3 \%$ strongly agreed. These results are in tandem with Flinders (2006) whose research results revealed that in the United Kingdom, it is a requirement for the Ministers give accurate information to Parliament as responses to issues raised during plenary and Committees of Parliament without any encumbrances. The Ministers who deliberately offers wrong information to Parliament required to resign his/her position. Information is to be given to Parliament whenever needed and any official who faults on provision of information should provide adequate explanation for such action. The information given to Parliament by members of the Executive is a fulfillment of Parliamentary oversight role. Similar views are also shared by Pelizzo \& Olson, (2006) whose study revealed that Parliamentary oversight is a critical indicator of a functioning parliament. Parliamentary accountability checks on government financial stewardship role and delivery of public services. Parliamentary oversight role is assessed based on set standard tools. In their study, results revealed that out of 49 countries, 47 Parliaments had complete data indicating use of oversight tools by legislators. The study also revealed that parliamentary oversight role reduces the risk of abuse of office and unconstitutional behaviour by governments.

As regards the issue of whether Parliament can ask the government for public clarification of policy, results revealed that all respondents agreed with the statement. The findings revealed that $73.1 \%$ of the respondents agreed, while $26.9 \%$ strongly agreed. The findings are in tandem with Mills (2017) who contends that parliamentary transparency and accountability increase access to information by Members of Parliament. The study also revealed that increased information about Members of Parliament helps to reduce diversionary thinking and align their policy views with those of the voters. Access to information by voters from their Members of Parliament helps Members of Parliament to spend less during campaign period. Members of Parliament have an obligation to share reports with the public presented to Parliament by Public Accounts Committee as a good practice that promotes information sharing.

Findings on whether Parliament can obtain information from sources outside the government revealed that all respondents agreed on this item. The findings revealed that $74.1 \%$ of the respondents agreed, while $25.9 \%$ strongly agreed. These results are in tune with Lokeris \& Muloni (2014) who explain that the Uganda oil and gas policy was initiated by government of Uganda to guide the management the nascent hydrocarbon industry. The hydrocarbon industry policy was formulation through a wide 
consultative process. A key informant from the Ministry of Energy and Mineral Development reported to Parliament during Plenary that:

In regard to the amount of oil that we have in place, so far we have established three and half billion barrels from only 40 per cent of the area covered. So, as we move forward we expect more discoveries and, therefore, the period of exploration, development and production would inevitably change. So, these facilities which we are putting in place could even serve beyond, when you look at oil from the neighbouring countries, in the event that we exhaust what we have in the country (Field data, 2017).

This claim was assessed based on Hansard to establish whether political parties through political party representation had balanced debates concerning hydrocarbon policies and the Parliamentary records showed that Members of the ninth Parliament were involved in oil and gas policy discussions both at Committee and Plenary levels.

Findings on whether Parliament can express its views to the government and the public revealed that all respondents agreed with the item i.e. $76.7 \%$ of the respondents agreed, while $23.3 \%$ strongly agreed. These results are in agreement with Saiegh, (2005) whose findings on Private Members' legislation revealed that parliament plays a legislative role in any democratic country and Acts of Parliament are debated and adopted by Parliament. The Members of Parliament can present Private Members' Bill for debate rather than the Cabinet Ministers. Parliament through its oversight role can demand reports from government for scrutiny. The Parliamentary Commission veto members proposed by the President to take up public offices. A key informant who happens to be a political party leader of DP questioned the relevance of Inter Party Organization for Dialogue (IPOD) in reference to platforms established to generate consensus on policy choices in Uganda and had this to say during media interview:

We appreciate the power of dialogue in solving political differences, but for the very long time, we have been pointing out NRM's failure to observe resolutions of the IPOD on its part. The summit has never met, so it would be better to create other avenues other than waste time there. Policy dialogue and negotiation become impossible because different political parties do not have a reliable platform for meetings (Field data, 2017).

The findings are also supported by Norris (2005), who opined that political parties serve several functions that include: harmonizing divergent public demands into consolidated policy proposals for debate and adoption by government; helping to recruit and train legislative candidates for political leadership; helping voters to make political choices basing on party manifestos and proposed programmes. Political parties are, therefore, cornerstones for democratic governance (Lehoucq \& Edouard, 2006). Evrard (2012) contends there are always policy changes depending on circumstances and political organizations will always to their previous policy performance to determine new election strategies.

\subsection{Interparty Organization for Dialogue and Policy Debates in Parliament}

On the fifteenth item, when respondents were asked to give their views on whether Parliament can express its views to the government and the public, their opinions were similar. The findings revealed that $76.7 \%$ of the respondents agreed, while $23.3 \%$ strongly agreed. The calculated Mean $(\mu=4.23$, $S D=.424)$. All respondents agreed that Parliament can express its views to the government and the public which had a high response level. The Standard Deviation shows that there was no variation in the responses.

According to Otjes \& Louwerse (2014), minority government affected patterns of legislative behavior. Minority governments usually operate through their parties but only share policy ideas during coalition meetings. Tsebelis \& Ha (2015) argue that coalitions have influence over public policy process but the challenge is conflicting ideological orientation. White (2018) contends that political parties always form alliances to champion their political agenda. Opposition parties often tend to lean on their party ideology and philosophy which in most cases, affect sustainability of the alliance. In a related study Krauss (2018) explains that coalition agreements signed by political parties risk early termination due to conflict political interests. It is recommended that parties forming a coalition should understand and harmonize divergent political interests and assure members of adherence to clauses embedded in the agreement. 
Inter Party Organization for Dialogue in Uganda is a political platform was established in 2010 with support of development partners to bring political parties together to promote good governance, tolerance and negotiation through discussions on matters of national importance. However, since its inception, NRM, DP, UPC and FDC have never met to discuss any matter of national importance. In other words, it is a dead platform and cannot be referred to among avenues that can be relied on to address stand offs in Uganda's political environment. This political platform also recognizes political parties with representation in Parliament but ignores the inputs of any other registered other political parties in Uganda. It can, therefore, be observed that the dialogue in political spectrum is limited and only favours political parties in Parliament regardless of their numerical strength. Opposition political parties decry of NRM intentions to frustrate IPOD but chairpersonship has been rotational and nothing meaningful has been documented as a measure of institutional political success in Uganda given its major objective. It can be observed that the legal framework to enforce IPOD resolutions is very weak and actions in this platform are guided by Memorandum of Understanding among political parties and that is why other political party leaders from FDC referred to it as:

The IPOD is long dead, but its burial has failed to take place. Our colleagues insisting on being there is like fighting over a corpse (Field data, 2017).

A key informant who is the Minister of information in NRM government whose views were captured using documentary review guide said:

There was no need for dialogue on political issues because there is a constitutional framework that specifies how things should be done, adding that Dr. Besigye is living in denial (Field data, 2017).

These statements presuppose that IPOD could have good intentions but political parties are simply not willing to meet and dialogue to build consensus on matters of national importance. It is also sought that issues to be raised could go personal or diversionary in nature and, therefore, become confrontational. Dialogue meetings suggest disagreement or contradictory policy agenda which means mediation is more important as a way of resolving political and policy issues than IPOD platform.

The National Dialogue meeting organized by the Elders Forum of Uganda, the Inter-Religious Council of Uganda and members of the Civil Society Organizations expected to be launched on November 21, 2018 by the President is yet to deliver tangible political outcome or what the five opposition leaders and other actors termed as "national crisis". The opposition political parties in Parliament listed seven political demands for National Dialogue that include: agenda of the National Dialogue; composition of the participants; modalities of convening and facilitating the dialogue and agreeing on independent financing the dialogue. Other demands include: guarantees on implementation of the outcome and guarantee from government on stop political repression, impunity, and freedom of political activities. The opposition political party leaders are emphatic on the issue of a clear agenda that will guarantee mutual respect for the outcome of the talks. One of the opposition political party leaders said that:

Our country is in the grip of a grave national crisis. The situation has become highly toxic and explosive. The toxic atmosphere has now infused all sectors and all levels of our national life. There is need for a serious, genuine and well - prepared national dialogue to address this critical crisis (Field data, 2018).

Another opposition political party leader provided a justification for a National Dialogue meeting and his reasoning focused on confidence, trust and respect of the meeting and had the following to say:

It is clear to us, the undersigned political leaders, in order to ensure that such a national dialogue is serious, genuine, well - prepared and fruitful, it is absolutely necessary to agree on and put in place these elements before embarking on the process of dialogue. We have engaged the group that is trying to organize the national dialogue. We need together to agree beforehand to those issues that will be discussed because Ugandans feel we should be talking to each other (Field data, 2018).

It is on record that Uganda has for the last fifty six years of independence never had a chance for National Dialogue and conditions opposition political party leaders were presenting were raised since 2011 and nothing achieved. But the government Deputy Spokesperson argued: 
Analysis of Political Parties Representation in Parliament Influence Public Policy Formulation in Uganda's Nascent Hydrocarbon Industry

Let them sit down as the opposition; come up with what they think should form the points of discussion and put them to the conveners. As government, we will take care of these issues that they think we should do (Field data, 2018).

A member of Civil Society Organization emphasized the need for National Dialogue meeting his argument was that it should be beyond Museveni - Besigye. He had this to say:

The citizen manifesto since 2008 has pointed out serious historical faultiness in nation building and a country; we have never sat down dialogue to deal with faultiness (Field data, 2018).

However, it can be observed from the discussions that neither the opposition political party leaders nor government is comitial on issues that should form basis for the national dialogue meeting. The organizers of the National Dialogue meeting also seem to be limited on what should form the agenda of the National Dialogue meeting. It therefore, no doubt that the National Dialogue meeting will yield any meaningful political outcome in Uganda's current political environment.

The average Mean obtained through the analysis of all the fifteen elements under this objective was 2.0, interpreted as high influence in terms of relationship between political parties' representation in Parliament and public policy formulation in Uganda's nascent hydrocarbon industry. The average Standard Deviation was $(S D=0.4694)$ meant that there was no much variation in the responses on all the fifteen elements.

Table3: Regression analysis on the relationship between political parties' representation in Parliament on public policy formulation in hydrocarbon industry

\begin{tabular}{l}
\hline \multicolumn{8}{|l|}{ Model Summary showing the relationship between political parties' representation and public policy } \\
formulation in Uganda's nascent hydrocarbon industry. \\
\hline Model
\end{tabular}

Source: Field Data, 2016

In determining the effect of political parties' representation in Parliament on public policy formulation in Uganda's nascent hydrocarbon industry, a null hypothesis (i) one was used. The researcher used regression to estimate a set of coefficients that represent the effect political parties' representation in Parliament on public policy formulation in Uganda's nascent hydrocarbon industry. According to the sample used (218) the degrees of freedom (df) is far beyond the one given for 100 in the Pearson Chi - Square. As the sample size becomes big, our sample tends to normal distribution and we can use the value for $\mathrm{df}=100$. Our levels of significance were $5 \%$ and the corresponding critical value 77.93 but the calculated $F$ value is less than 0.0001 . Since the $F$ value is far below the critical $\alpha=$ of 0.05 , then we reject $H_{0}$ and we conclude that political parties' representation in Parliament influence public policy formulation in Uganda's hydrocarbon industry. The results show that political party representation contributes to public policy formulation in Uganda's nascent hydrocarbon industry by $14.2 \%$. This implies that a unit increase in political parties' representation improves public policy formulation by $14.2 \%$ and it is significant $(\mathrm{P}=0.000)$ meaning political parties' representation is a significant determinant of public policy formulation in Uganda's nascent hydrocarbon industry.

\section{Conclusions}

From the study findings, it is concluded that; political party representation contributes to public policy formulation in Uganda's nascent hydrocarbon industry by $14.2 \%$. Political party representation is a significant contributor to public policy formulation in Uganda's nascent hydrocarbon industry. It is concluded that these findings are in agreement with previous studies done on public policy formulation. Political parties with a high number of Members of Parliament in the House will influence public policy formulation in Parliament. It can also be concluded that opposition political parties when they form alliances or coalitions, can influence public policy formulation in Parliament. The opposition political parties are highly fragmented and this makes them too weak to engage the ruling party on any policy matter in Parliament. In the tenth Parliament, NRM has 293 seats, Opposition has 57 and Independent Members of Parliament are 66 and the party in power dominates policy debates and policies tend to favour the regime in power. 


\section{RECOMMENDATIONS}

The following recommendations were made; political parties should always endeavor to increase their numbers in Parliament in order to influence public policy formulation. Political parties should strategically mobilize and second their members to contest for parliamentary seats to ensure that they have more members in Parliament. It is recommended that political parties should embark on aggressive mobilization for their candidates to win elections so as to have more seats in parliament to influence public policy process.

The current politics in Uganda is politics of numbers to influence policy direction in Parliament. Members of respective political parties should ensure to have more representation in Committees of Parliament where policy scrutiny is done to inform parliament on different policy options available for debate. Political parties with fewer members in Parliament should form alliances with the one with majority members if they are to have any meaningful contribution to public policy formulation because if they do not, they may be ignored.

It is recommended that opposition political parties should reconcile their differences and constitute a strong super alliance by merging all small parties and independent members of parliament to challenge for not only State power but also negotiate policy position with the ruling party in Uganda. Key oil and gas companies in the hydrocarbon industry should not antagonize with the political party with majority seats in parliament as this can jeopardize their operations since a policy may be made against them.

Political parties should strengthen the operation and functionality of Inter Party Organization for Dialogue. Political parties with representation in parliament which include: NRM, FDC, DP and UPC and reconcile their political differences that affect attempts for dialogue. Political parties should use dialogue and negotiations to resolve contentious policy issues. For public policy formulation to succeed, roundtable negotiations and dialogue meetings are paramount to generate consensus on matters affecting the management of the hydrocarbon industry.

A neutral party is required to effectively handle matters raised in the meeting which seem to be lacking in current IPOD arrangement. For IPOD to function effectively, political parties should review the current legal and operational challenges and propose amendments that can address current lacunas in the law so that partners will be willing and ready to dialogue without any hindrances.

Centers of responsibility should be defined and sanctions clearly stated to hold any political party responsible in case of any failure to compile with stated IPOD guiding principles. To improve public policy formulation, political parties competing for power should review and endorse policies that are deemed relevant and beneficial to the entire population. There must be a forum political parties that brings together to discuss individual party proposals in a free and fair environment. Political parties should adopt new campaign strategies that can attract new members to join their parties to influence the voting pattern and win both local election and take state power.

\section{REFERENCES}

[1] Ablo, A. D. (2015). Local content and participation in Ghana's oil and gas industry: Can enterprise development make a difference? https://www.academia.edu/32004492/Local_content_and_ participation_ in_Ghanas_oil_and_gas_industry_Can_enterprise_development_make_a_difference. Accessed on 30/03/2019.

[2] African Election Database (2008-2010). A database of election results in Sub-Saharan Africa. http://africanelections.tripod.com/ug.html. Accessed on 28/04/2019.

[3] Amin, M. E. (2005). Social science research: conception, methodology and analysis. Makerere University, Kampala - Uganda.

[4] Adar, K. G., Hamdok, A., \& Rukambe, J. (2008). Electoral process and the prospects for democracy consolidation: contextualising the African multiparty elections of 2004. Pretoria, South Africa: Institute of South Africa.

[5] Agozino, B. (2015). The Whip in the House: Rituals of Social control in Parliament and in Society. Social Crimonol. Vol. 3, Issue No. 1, pp. 1-6.

[6] Agresti, A. (2011). Modeling Ordinal Categorical Data. PhD School in Statistics, Department of Statistical Sciences. University of Florida, USA. https://www.stat.unipd.it/sites/default/files/Agresti_May2011.pdf. Accessed on 15/02/2019.

[7] Alemán, E., \& Tsebelis, G. (2011). Political Parties and Government Coalitions in the Americas. Journal of Politics in Latin America, Vol. 3, Issue No. 1, pp. 3-28. 
Analysis of Political Parties Representation in Parliament Influence Public Policy Formulation in Uganda's Nascent Hydrocarbon Industry

[8] Anderson, C. J., \& Guillory, C. A. (1997). Political Institutions and Satisfaction with Democracy: A CrossNational Analysis of Consensus and Majoritarian Systems. American Political Science Review, Vol. 91, Issue No. 01, pp. 66-81.

[9] Arter, D. (2018). The What, Why's and How's of Constituency Service. Journal of Representative Democracy, Vol. 54, Issue No. 1, pp. 5-21.

[10] Aurel, B., \& Wolfgang, C. (1998). Political Party Formation in Presidential and Parliamentary System. Institute for Political Science of the University of Heidelberg, Philippine. http://library.fes.de/pdf-files /bueros/philippinen/50072.pdf. Accessed on 19/03/2019.

[11] Bainomugisha, A. (2006). Political Parties, Political Change and Environmental Governance in Uganda: A Review of Political Parties Manifestos. Advocates Coalition for Development and Environment (ACODE). https://www.acode-u.org/Files/Publications/PRS_16.pdf. Accessed on 17/03/2019.

[12] Banfield, J. (2011). Oil and Gas Laws in Uganda: A Legislators' Guide. Oil Discussion Paper No. 1. Understanding conflict. Building peace. https://www.international-alert.org/sites/default/files/publications /18-Oil-web.pdf. Accessed on 06/04/2019.

[13] Bategeka, B. L., Kiiza, J., \& Ssewanyana, S. (2013). Oil Discovery in Uganda: Managing Expectations. Economic Policy Research Centre and Makerere University. https://www.mak.ac.ug/documents/ EPRCUDICPaper.pdf. Accessed on 19/03/2019.

[14] Bernstorff, J.V. (2007). Non-State Actors in law-making and in the shaping of policy. On the legality and legitimacy of NGO Participation in International Law. Study for the preparation of the Konrad-AdenauerFoundation's Conference on International Law 2007. https://www.kas.de/c/document_library/get_file? uuid=4e2e1560-2408-8bfd-9f85-5dea3e38c200\&groupId=252038. Accessed on 25/03/2019.

[15] Bøggild, T., \& Pedersen, H. H. (2018). Campaigning on behalf of the party? Party constraints on candidate campaign personalisation. European Journal of Political Research, Vol. 57, Issue No. 4, pp. 883-899.

[16] Bräuninger, T., Debus, M., \& Wüst, F. (2017). Governments, Parliaments and Legislative Activity. Political Science Research and Methods, Vol. 5, Issue No. 03, pp. 529-554.

[17] Brouard, S., Grossman, E., Guinaudeau, I., Persico, S., \& Froio, C. (2018). Do Party Manifestos Matter in PolicyMaking? Capacities, Incentives and Outcomes of Electoral Programmes in France. Political Studies, pp. 1-19.

[18] Bunn, M. L. (2017). The Development of Public Sector Audit Independence: The Colonial Experience in Western Australia. School of Accounting Curtin Business School.

[19] Carbone, G. M. (2005). Populism'visits Africa: the case of Yoweri Museveni and no-party democracy in Uganda. Crisis States Research Centre working papers series 1 (73). Crisis States Research Centre, London School of Economics and Political Science, London, UK.

[20] Carley-baxter, L. R., Hill, C. A., Roe, D. J., Twiddy, S. E., Baxter, R. K., \& Ruppenkamp, J. (2009). Does Response Rate Matter? Journal Editors Use of Survey Quality Measures in Manuscript Publication Decisions. Survey Practice, Vol. 2, Issue 7, 2009.

[21] Chigora, P., Guzura, T., \& Mutumburanzou, J. (2011). The challenges facing Opposition Political Parties in Rural Zimbabwe within 2000-2008. African Journal of Political Science and International Relations Vol. 5, Issue No. 7, pp. 358-366.

[22] Chunga, B. J. J. (2014). Examining the Relevance of Political Parties in Malawi. https://www.africaportal. org/publications/examining-the-relevance-of-political-parties-in-malawi/. Accessed on 01/04/2019.

[23] Christova, A. (1999). The Role of National Parliaments in the Decision-Making Mechanism of the North Atlantic Treaty Organization. https://www.nato.int/acad/fellow/97-99/christova.pdf. Accessed on 12/03/ 2019.

[24] Chungong, M. (2017). Global Parliamentary Report 2017. Parliamentary oversight: Parliament's power to hold government to account. Inter-Parliamentary Union and United Nations Development Programme, 2017. Printed in France by Courand et Associés.

[25] Collord, M. ( 2016). From the electoral battleground to the parliamentary arena: understanding intra-elite bargaining in Uganda's National Resistance Movement. Journal of East African Studies, Vol. 10, Issue No. 4, pp. 639-659.

[26] Cowley, P. \& Stuart, M. (2015). Whipping Them in: Role-Playing Party Cohesion with a Chief Whip. Journal of Political Science Education, Vol. 11, Issue No. 2, pp. 190-203.

[27] Creswell, J.W. (2009). Research Design: Qualitative, Quantitative, and Mixed Methods Approaches (3rd ed.). Thousand Oaks, CA: Sage Publications.

[28] Cross, W., \& Young, L. (2008). Factors influencing the Decision of the Young Politically engaged to join a Political Party: An investigation of the Canadian case. Party Politics, Vol. 14, Issue No. 3, pp. 345-369.

[29] Curini, L., Hino, A., \& Osaka, A. (2018). The Intensity of Government - Opposition Divide as Measured through Legislative Speeches and What We Can Learn from It: Analyses of Japanese Parliamentary 
Analysis of Political Parties Representation in Parliament Influence Public Policy Formulation in Uganda's Nascent Hydrocarbon Industry

Debates, 1953 - 2013. Government and Opposition, pp.1-18.

[30] Daley, G. (2014). Beginnings for Understanding the Politics of Public Policy in Jamaica. International Journal of Political Science and Development, Vol. 2, Issue No. 10, pp. 237-247.

[31] Dalton, R. J. (1985). Political Parties and Political Representation. Comparative Political Studies, Vol. 18, Issue No. 3, pp. 267-299.

[32] Davis, C. L., Camp, R., \& Coleman, K. M. (2016). The Influence of Party Systems on Citizens' Perceptions of Corruption and Electoral Response in Latin America. Comparative Political Studies, Vol. 37, Issue No. 6, pp. 677-703.

[33] Dawkins, R. (2017). Political participation, personality, and the conditional effect of campaign mobilization. Electoral Studies, Vol.45, pp. 100-109.

[34] Doro, E., \& Kufakurinani, U. (2018). Resource Curse or Governance Deficit? The Role of Parliament in Uganda's Oil and Zimbabwe's Diamonds. Journal of Southern African Studies, Vol. 44, Issue No. 1, pp. 43-57.

[35] Draman, R. (2012). Measuring Parliamentary Performance - The African Parliamentary Index (API). A Summary Report of the API Round II Assessments in Seven African Countries, 2012. Parliamentary Centre 2013, Ottawa - Canada.

[36] Eggers, A. C., \& Spirling, A. (2015). The Shadow Cabinet in Westminster Systems. Opposition Agenda Setting in the House of Commons. https://www.nyu.edu/projects/spirling/documents/bursty.pdf. Accessed on $10 / 04 / 2019$.

[37] Ennser-jedenastik, L. \& Wolfgang, C. (2015). Intra-party Democracy, Political performance and the survival of party leaders: Austria, 1945 - 2011. Party Politics, Vol. 21, Issue No. 6, pp. 930-943.

[38] Evrard, A. (2012). Political Parties and Policy Change: Explaining the Impact of French and German Greens on Energy Policy. Journal of Comparative Policy Analysis: Research and Practice, Vol. 14, Issue No. 4, pp. 275-291.

[39] Enyedi, Z. (2016). Populist Polarization and Party System Institutionalization. The Role of Party Politics in De-Democratization. Problems of Post-Communism, Vol. 63, Issue No. 4, pp. 210-220.

[40] Field, A. (2009). Discovering Statistics Using SPSS. London: Sage Publications Ltd.

[41] Flinders, M. (2006). Volcanic Politics: Executive - Legislative Relations in Britain, 1997 - 2005. Australian Journal of Political Science, Vol. 41, Issue No. 3, pp. 385-406.

[42] Franchino, F., \& Hyland, B. (2009). Legislative involvement in parliamentary systems: Opportunities, conflict, and institutional constraints. American Political Science Review, Vol. 103, Issue No. 4, pp. 607-621.

[43] Gauja, A. (2015). The construction of party membership. European Journal of Political Research, Vol. 54, Issue No. 2, pp. 232 - 248.

[44] Giannetti, D., \& Laver, M. (2005). Party cohesion, party discipline, and party factions in Italy. Intra-Party Politics and Coalition Governments. https://www.researchgate.net/publication/228951709_Party_ cohesion_party_factions_and_legislative_party_discipline_in_Italy. Accessed on 30/03/2019.

[45] Gibb, R. (2016). The Elections in Uganda, February 2016. Africa Spectrum, Vol. 51, Issue No. 2, pp. $93-101$.

[46] Gobo, G. (1967). Sampling, representativeness and generalizability. https://ggobors.ariel.ctu.unimi.it/ repository/ggobors/sage2004.pdf. Accessed on 30/03/2019.

[47] Goldsworthy, J. (2012). Parliamentary Sovereignty's Premature Obituary. UK Constitutional Law Association. https://ukconstitutionallaw.org/2012/03/09/jeffrey-goldsworthy-parliamentary-sovereigntyspremature-obituary/. Accessed on 11/04/2019.

[48] Golooba-Mutebi, F., \& Hickey, S. (2016). The master of institutional multiplicity? The shifting politics of regime survival, state-building and democratisation in Museveni's Uganda. Journal of Eastern African Studies, Vol. 10, Issue No. 4, pp. 601-618.

[49] Green, B. (2014). Personal Construct Psychology and Content Analysis. Community Forensic Mental Health Service, Brisbane, Qld, Australia. https://www.researchgate.net/publication/255574512_Personal_ construct_psychology_and_content_analysis/download. Accessed on 06/04/2019.

[50] Greg, P \& Shoot, R. A. (2012). Global Parliamentary Report. The Changing Nature of Parliamentary Representatives. http://archive.ipu.org/pdf/publications/gpr2012-full-e.pdf. Accessed on 02/04/2019.

[51] Gromet, D. M., Kunreuther, H., \& Larrick, R. P. (2013). Political ideology affects energy-efficiency attitudes and choices. Proceedings of the National Academy of Sciences, Vol. 110, Issue No. 23, pp. 9314-9319.

[52] Gutmann, A., \& Thompson, D. (2010). The Mindset of Political Compromise. https://president.upenn.edu/ meet-president/mindsets-political-compromise. Accessed on 11/04/2019.

[53] Gould, J. A., \& Winters, M. S. (2012). Petroleum blues: The political economy of resources and conflict in Chad. https://www.researchgate.net/publication/260400319_Petroleum_Blues_The_Political_Economy_ 
Analysis of Political Parties Representation in Parliament Influence Public Policy Formulation in Uganda's Nascent Hydrocarbon Industry

of_Resources_and_Conflict_in_Chad/download. Accessed on 02/04/2019.

[54] Hai, D. (2013). Process of Public Policy Formulation in Developing Countries. Faculty of Public Policy Graduate Academy of Social Science (GASS), Vietnam. http://www.politicipublice.ro/uploads/public _ policy_formulation.pdf. Accessed on 30/03/2019.

[55] Hanlon, B. (2011). Samples and Populations. https://www.stat.wisc.edu/courses/st371-hanlon/notes/chap2samples.pdf. Accessed on 03/04/2019.

[56] Harrison, L. (2014). The Role of National Parliaments in the European Union. House of Lords European Union Committee, 9th Report of Session 2013-14 . Published by the Authority of the House of Lords London.

[57] Heidar, K., \& Karlsen, R. (2018). All about the Party? Constituency Representation - and Service-in Norway. Representation, Journal of Representative Democracy, Vol. 54, Issue No. 1, pp. 69-85.

[58] Heinze, A. (2017). Strategies of mainstream parties towards their right-wing populist challengers: Denmark, Norway, Sweden and Finland in comparison. West European Politics, Vol. 41, Issue No. 2, pp.287-309.

[59] Heitshusen, V. (2017). The Speaker of the House: House Officer, Party Leader, and Representative. Congressional Research Service, Informing the Legislative debate since 1914.

[60] Hindmoor, A., Larkin, P., \& Kennon, A. (2009). Assessing the Influence of Select Committees in the UK: The Education and Skills Committee, 1997-2005. The Journal of Legislative Studies.

[61] Hix, S. (2002). Constitutional Agenda-Setting through Discretion in Rule Interpretation: Why the European Parliament Won at Amsterdam. British Journal of Political Science, Vol. 32, Issue No. 02, pp. 259-280.

[62] Hix, S., \& Noury, A. (2016). Government-Opposition or Left-Right? The Institutional Determinants of Voting in Legislatures. Political Science Research and Methods, Vol. 4, Issue No. 02, pp. 249-273.

[63] Hobolt, S. B., \& Tilley, J. (2016). Fleeing the centre: the rise of challenger parties in the aftermath of the euro crisis the aftermath of the euro crisis. West European Politics, Vol. 2382, pp. 1-21.

[64] Holzhacker, R. (2002). National Parliamentary Scrutiny over EU Issues. Comparing the Goals and Methods of Governing and Opposition Parties. European Union politics. Vol. 3 (4): 459 - 479.

[65] House of Commons Information Office. (2010). Private Members' Bills Procedure. House of Commons Information Office. Factsheet L2 Legislation Series Revised June 2010. https://www.parliament.uk/ documents/commons-information-office/102.pdf. Accessed on 06/04/2019.

[66] Howlett, M., Kuan, L., \& Shivakoti, R. (2014). Agenda-Setting Tools: State-Driven Agenda Activity from Government Relations to Scenario Forecasting Introduction: Non-Implementation Tools and Public Policy -Making. https://www.academia.edu/35365072/Agenda-Setting_Tools_State-Driven_Agenda_Activity_ from_Government_Relations_to_Scenario_Forecasting. Accessed on 06/04/2019.

[67] Ilie, C. (2014). Discourse and metadiscourse in parliamentary debates. Journal of Language and Politics, Vol. 2, Issue No.1, pp. 71-92.

[68] Izama, A., \& Okao, T. O. (2011). Status of Uganda's Oil and Gas Legislation. Advocates Coalition for Development and Environment. Extending the frontiers of knowledge for development and transformation. Infosheet No. 14, 2011. https://www.acode-u.org/Files/Publications/infosheet_14.pdf. Accessed on 03/04/2019.

[69] Jans, T., \& Piedrafita, S. (2009). The Role of National Parliaments in European. http://aei.pitt.edu/12376/ 1/20090709111616_Art3_Eipascoop2009_01.pdf. Accessed on 06/04/2019.

[70] Jinadu, L. A. (2011). Inter-Party Dialogue in Ngeria: Examining The Past, Present \& Future. https://www. vanguardngr.com/2011/10/inter-party-dialogue-in-ngeria-examining-the-past-present-and-

future/https://www.vanguardngr.com/2011/10/inter-party-dialogue-in-ngeria-examining-the-past-presentand-future/. Accessed on 04/04/2019.

[71] Juma, K. S. (2011). Voting behaviour in Uganda since 1996: An investigation into the factors likely to determine voters' choices in the 2011 elections. Journal of Political Science, Vol. 5, pp. 21-29.

[72] Kakuba, J. S. (2010). Multiparty Politics Dynamics in Uganda. African Journal of Political Science and International Relations, Vol. 4, Issue No. 3, pp. 109-114.

[73] Kamp, M., \& Kiranda, Y. (2010). The State of Multiparty Democracy in Uganda. REALITY CHECK. Konrad-Adenauer-Stiftung, Uganda Programme. Kampala, Uganda.

[74] Karugire, S. R. (1980). A Political History of Uganda. Published by Heinemann Educational Books. Narobi, Kenya. First published 1980. Printed by Kenya Litho Ltd, Nairobi.

[75] Kasimbazi, E. B. (2012). Environmental Regulation of Oil and Gas Exploration and Production in Uganda. Journal of Energy \& Natural Resources Law, Vol. 30, Issue No. 2, pp. 185-221.

[76] Keefer, P. (2015). Political Parties and the Politics of the Quality of Government. https://link.springer. com/chapter/10.1057/9781137556288_13. Accessed on 30/03/2019.

[77] Kiiza, J. (2005). The Role of Opposition Parties in a Democracy. Department of Political Science and 
Analysis of Political Parties Representation in Parliament Influence Public Policy Formulation in Uganda's Nascent Hydrocarbon Industry

Public Administration, Makerere University. http://www.kasyp.net/fileadmin/kasyp_files/Documents/ reused/documents/analysisandpub/party_system/the-role-of-opposition-parties-in-a-democracy1.pdf. Accessed on 29/03/2019.

[78] Khisa, M. (2017). Managing elite defection in Museveni's Uganda: the 2016 elections in perspective. Journal of East African Studies, Vol. 10, Issue No. 4, pp. 729-748.

[79] Korn, D. (1992). National Coalitions in Israel, 1984-1990: The Politics of "Not Losing. A Thesis for the degree of Ph.D. Presented to the University of London, London School of Economics. http://etheses.lse. ac.uk/2083/1/U549931.pdf. Accessed on 12/04/2019.

[80] Kothari, C. R. (2010). Research Methodology, Methods and Techniques. Second Edition. New Age International (P) Limited, Publishers, New Delhi.

[81] Krauss, S. (2018). Stability through control? The influence of coalition agreements on the stability of coalition cabinets. https://ecpr.eu/Filestore/PaperProposal/82f17383-bd0f-4590-bf63-1892254dafa0.pdf. Accessed on 30/03/2019.

[82] Kwagala-Igaga, D. (2012). Tax Reform in Uganda: Missed Opportunities and Prospects for State Building. https://papers.ssrn.com/sol3/papers.cfm?abstract_id=2609357. Accessed on 04/04/2019.

[83] Laver, M. (1997). Legislatures and Parliaments in Comparative Context. Forthcoming in: Barry Weingast and Donald Wittman (eds) Oxford Handbook of Political Economy. Oxford: Oxford University Press.

[84] Llanto, G. M. (2007). The Policy Development Process and the Agenda for Effective Institutions: The Philippines. The Micro Foundations of East Asian Economic Integration, Tokyo, Japan February 26, 2007. http://www.eaber.org/sites/default/files/Dr.\%20Llanto.pdf. Accessed on 05/04/2019.

[85] Lehoucq, F. E., \& Edouard, F. (2006). Policymaking, parties and institutions in democratic Costa Rica. https://libres.uncg.edu/ir/uncg/f/FLehoucq_Institutional_1996.pdf. Accessed on 06/04/2019.

[86] Leighninger, M. (2014). Infogagement: Citizenship and Democracy in the Age of Connection. http://www. pacefunders.org/publications/infogagement.pdf. Accessed on 05/04/2019.

[87] Lee, M. (2013). Are British political Parties converging at the "Centre Ground"? Journal of Politics \& International Studies, Vol.9, Issue No. 9, pp. 250 - 286.

[88] Leeper, T. J. (2014). Political Parties, Motivated Reasoning, and Public Opinion Formation. Advances in Political Psychology, Vol. 35, Issue No. 1, pp. 129 - 156.

[89] Levy, J. (2009). Strengthening Parliament's Powers of Scrutiny? An assessment of the introduction of Public Bill Committees. Published by The Constitution Unit Department of Political Science UCL, University College London.

[90] Liebig, J., Gießen, U., Masango, R., Njuru, J., Sørheim, I. B., \&Yagboyaju, D. A. (2014). Policy Formulation and Implementation. African Studies Quarterly, Vol. 11, pp. 392-3261.

[91] Lo, J., Proksch, S. O., \& Slapin, J. B. (2014). Ideological Clarity in Multi-Party Competition : A New Measure and Test Using Election Manifestos. British Journal of Political Science, Vol. 46, Issue No. 03, pp. 591 - 610.

[92] Lokeris, H. P., \& Muloni, I. (2014). The Republic of Uganda the Oil \& Gas Sector in Uganda Progress of Implementation of the National Oil. https://pau.go.ug/uploads/NATIONALOILANDGASPOLICYFOR UGANDA.pdf. Accessed on 05/04/2019.

[93] Lord, C. J. (2010). The aggregating function of political parties in EU Decision-making. Living Reviews in European Governance, Vol. 5, Issue No. 1, pp. 1-33.

[94] Magee, C. (2001). Campaign Contributions, Policy Decisions, and Election Outcomes: A Study of the Effects of Campaign Finance Reform. https://www.researchgate.net/publication/5163231_Campaign_ Contributions_Policy_Decisions_and_Election_Outcomes_A_Study_of_the_Effects_of_Campaign_Finan ce_Reform/download. Accessed on 30/03/2019.

[95] Magstadt, M. T. (2003). Understanding Politics: Ideas, Institutions, and Issues. Wadsworth/Thompson Learning Inc. Belmont, USA.

[96] Maiyo, J. (2010). Political parties and intra-party democracy in East Africa: Considerations for democratic consolidation, in Mirjam de Bruijn \& Daniela Merolla (eds) Researching Africa: Explorations of everyday African encounters. African Studies Centre, Leiden. African Studies Collection, Vol. 26, pp. 31-55.

[97] Maiyo, J. (2017). Political Parties and Intra-Party Democracy in Uganda. Challenges and Political Parties and Intra-Party Democracy in Uganda.The Netherlands Institute for Multiparty Democracy Working Paper. https://www.researchgate.net/publication/261062256_Political_Parties_and_Intra-Party_Democracy__ in_ Uganda_Challenges_and_Opportunities_for_Democratic_Consolidation/download. Accessed on 06/04/2019.

[98] Manual on the Legislative process in Uganda (2014). Ministry of Justice and Constitutional Affairs. The First Parliamentary Counsel. https://www.jlos.go.ug/index.php/2011-08-15-07-20-50/legislation/ legislative-processin-uganda. Acessed on 30/03/2019. 
Analysis of Political Parties Representation in Parliament Influence Public Policy Formulation in Uganda's Nascent Hydrocarbon Industry

[99] Marcel, V. (2016). The Cost of an Emerging National Oil Company. Research Paper, Energy, Environment and Resources. https://www.chathamhouse.org/sites/default/files/publications/research/201603-01-cost-emerging-national-oil-company-marcel.pdf. Accessed on 05/04/2019.

[100] Maseng, J. O. (2014). State and Non-State Actors in South African Public Policy. Africa Institute of South Africa, Briefing NO 107. file://C:/Users/Aron/Downloads/State-and-Non-State-Actors-inSouthAfrican-Public-Policy.pdf. Accessed on 04/04/2019.

[101] Mathison, S. (1988). Why Triangulate ?Educational Reearcher. https://journals.sagepub.com/doi/ 10.3102/ 0013189X017002013. Accessed on 04/04/2019.

[102] Mazaki, K. E. (2017). Staff Welfare and Teachers' Performance in Public Primary Schools in Bugisu Sub- Region in Uganda. Published PhD Thesis, UTAMU-Mbarara University of Science and Technology, Uganda.

[103] Mbete, L. (2016). An evaluation of oversight and accountability by the fourth Parliament of the Republic of South Africa. Published thesis for award of Master of Public Administration, Stellenbosch University, South Africa.

[104] Mills, L. (2017). Parliamentary transparency and accountability. Helpdesk reports, UK Department for International Development. https://gsdrc.org/publications/parliamentary-transparency-and-accountability/ .pdf. Accessed on 19/03/2019.

[105] Moore, M. K., \& Thomas, S. (1991). Explaining Legislative Success in the U.S. Senate: the Role of the Majority and Minority Parties. Political Research Quarterly, Vol. 44, Issue No. 4, pp. 959-970.

[106] Morison, J. (2017). Citizen Participation: A Critical Look at the Democratic Adequacy of Government Consultations. Oxford Journal of Legal Studies, Vol. 37, Issue No. 3, pp. 636-659.

[107] Mpyisi, K., \& Mwirichia, V. (2011). Situation Report Uganda: Analysis of and reflection on the 2011 elections. Summary Report of ISS Public Seminar. Organized by The African Conflict Prevention Programme (ACPP), ISS Nairobi Office in conjunction with the Hanns-Seidel Foundation and Deepening Democracy Programme- Kampala. https://reliefweb.int/sites/reliefweb.int/files/resources/Full_Report_ 101.pdf. Accessed on 24/03/2019.

[108] Müller, W. C. (2000). Political parties in parliamentary democracies: Making delegation and accountability work. European Journal of Political Research, Vol. 37, Issue No. 3, pp. 309-333.

[109] Mulyanyuma, A. A. (2016). The challenges in policy formulation policy analysis and implementation in developing countries. https://www.slideshare.net/mulyanyuma/the-challenges-in-policy-formulationpolicy-analysis-and-implementation-in-developing-countries. Accessed on 06/04/2019.

[110] Mutabazi, M. M. (2010). The political character of President Yoweri Kaguta Museveni: An indictment of Uganda's economic reforms and renaissance? Department of Sociology and Rural Studies South Dakota State University Brookings, 57006, SD.

[111] Myers, K., \& Mohammed, A. (2012). A Short Guide to Parliamentary Oversight of the Oil \& Gas Sector for Parliament of Ghana. https://www.parlcent.org/en/wp-content/uploads/2012/05/PC-MPs-Short-Guideon-Oil-Gas.pdf. Accessed on 30/03/2019.

[112] Namuyondo, E. (2013). Sustainability and Oil Exploration in Uganda - the case of Uganda's Albertine Region. https://projekter.aau.dk/projekter/en/studentthesis/sustainability-and-oil-exploration-in-uganda--thecase-of-ugandas-albertine-region(5d1fa846-660f-4059-b179-11481b09ffde).html. Accessed on 30/03/2019.

[113] Negri, F. (2017). Who Affects Government Declarations and Why? Contrasting the Left-Right Scale with the Welfare Dimension. Government and Opposition. https://www.researchgate.net/publication/ 320875473_Who_Affects_Government_Declarations_and_Why_Contrasting_the_LeftRight_Scale_with_the_Welfare_Dimension. Accessed on 21/04/2019.

[114] Neuman, W. L. (2013). Social research methods: qualitative and quantitative approaches. Seventh Edition, Pearson Education Limited Edinburgh Gate Harlow Essex CM20 2JE England and Associated Companies throughout the world.

[115] Njoroge, J. M. (2014). Role of the Kenyan Parliament in Promoting the East African Integration: 1963 to 2010. Published MA Thesis, University of Nairobi - Kenya.

[116] Nogoibaeva, C. (2014). Policy Making in the Executive Branch of the Government of the Kyrgyz Republic. Institute of Public Policy and Administration Working Paper No.29, 2014. University of Central Asia.

[117] Norris, P. (2005). Building political Parties: Reforming legal Regulations and Internal rules. Report for International IDEA: revised draft. McGuire Lecturer in Comparative Politics John F. Kennedy School of Government Harvard University Cambridge.

[118] Olanya, D. R. (2011). Political Functionalism as a Prerequisite for Political Development: Evidence From Uganda's General Elections 2011. Journal of US-China Public Administration, Vol. 8, Issue No. 12, pp. 1352-1366.

[119] Oloka-Onyango (1992). Governance, Democracy and Development in Uganda Today: A Socio-Legal Examination. African Study Monographs, Vol. 13, Issue No. 2, pp. 91-109.

[120] Osabiya, B. J. (2015). Political Parties and Democratic Governance in Africa: A Case Study of a Political 
Analysis of Political Parties Representation in Parliament Influence Public Policy Formulation in Uganda's Nascent Hydrocarbon Industry

Party in Nigeria (The Peoples Democratic Party ( PDP) from 1999 - 2015. American International Journal of Research in Humanities, Arts and Social Sciences, Vol. 11, Issue No. 2, pp. 163-168.

[121] Otjes, S., \& Louwerse, T. (2014). A Special Majority Cabinet? Supported Minority Governance and Parliamentary Behavior in the Netherlands. World Political Science Review, Vol.10, Issue No. 2, pp. 343-363.

[122] Pelizzo, R., \& Olson, D. (2006). Parliamentary Oversight for Government Accountability. Institutional Knowledge at Singapore Management University. https://ink.library.smu.edu.sg/cgi/viewcontent.cgi? article $=1136 \&$ context $=$ soss_research. Accessed on 29/03/2019.

[123] Pojani, D., Stead, D., Bruun, E.,\& Goyet, C. (2011). The constitution of the Republic of Uganda. Parliamentary Affairs, Vol. 2, Issue No. 256, pp. 1-44.

[124] Political Parties and Organization Act (PPOA). https://www.ec.or.ug/docs/Political\%20Parties\%20and $\% 20$ Organisations\%20(Amendment)\%20Act\%202010.pdf. Accessed on 06/04/2019.

[125] Rasmussen, K. A. (2010). Kinna-Uganda: A review of Uganda's national cinema. ProQuest Dissertations and Theses, 117. https://scholarworks.sjsu.edu/cgi/viewcontent.cgi?article=4889\&context=etd_theses. Accesed on 30/03/2019.

[126] Raunio, T. (2009). National Parliaments and European Integration: What we know and what we should know. The Journal of Legislative Studies, Vol. 15, Issue No. 4, pp. 25.

[127] Rose-Ackerman, S. (2004). The Challenge of Poor Governance and Corruption. This paper was produced for the Copenhagen Consensus 2004 project. Law and Political Science, Yale University. https://www. copenhagenconsensus.com/sites/default/files/cp-corruptionfinished.pdf. Accessed on 11/04/2019.

[128] Rules of Procedure of the Parliament of Uganda (2006). Republic of Uganda. The Parliament of Uganda. https://publicofficialsfinancialdisclosure.worldbank.org/sites/fdl/files/assets/law-libraryfiles/Uganda_Rules\%20of\%20Procedure\%20of\%20Parliament_2006_en.pdf. Accessed on 17/03/2019.

[129] Russell, M \& Paun, A. (2006). Managing Parliament Better? A Business Committee for the House of Commons. The Constitution Unit Department of Political Science UCL (University College London).

[130] Russell, M., \& Cowley, P. (2016). The Policy Power of the Westminster Parliament: The "Parliamentary State" and the Empirical Evidence. Governance, Vol. 29, Issue No. 1, pp. 121-137.

[131] Russell, M., Gover, D., Wollter, K., \& Benton, M. (2017). Actors, Motivations and Outcomes in the Legislative Process: Policy Influence at Westminster. Government and Opposition, Vol. 52, Issue No. 1, pp. 1-27.

[132] Saiegh, S. M. (2005). The Role of Legislatures in the Policymaking Process. Department of Political Science University of Pittsburgh. Prepared for delivery at the Workshop on State Reform, Public Policies and Policymaking Processes, Inter-American Development Bank, Washington D.C., Feb. 28-Mar. 2, 2005. Accessed on 05/04/2019.

[133] Sebastian, S. M. (2005). The Role of Legislatures in the Policymaking Process. Department of Political Science University of Pittsburgh.

[134] Ssemogerere, P. K. (2011). Reality check: political party financing in Uganda: a critical analysis in reference to other countries. Konrad Adenauer Stiftung, Kampala, Uganda.

[135] Schmidt, M. G. (2002). Political performance and types of democracy: Findings from comparative studies. European Journal of Political Research, Vol. 41, Issue No. 1, pp. 147-163.

[136] Schwarz, D., \& Ladner, A. (2009). The half-life of election pledges. What makes MPs change their positions? In: Swiss Electoral Studies (Selects) workshop "Voting behavior and campaign dynamics in the Swiss National Elections 2007", Neuchâtel, 23 October 2009 - 24 October 2009. https://www.zora. uzh.ch/id/eprint/27955/. Accessed on 03/04/2019.

[137] Steinack, K. (2011). Two Patterns of Opposition: Party Group Interaction in the Bavarian State Parliament. Journal of Legislative Studies, Vol. 17, Issue No. 1, pp. 1-26.

[138] Strom, K. (1990). A Behavioral Theory of Competitive Political Parties. American Journal of Political Science, Vol. 34, Issue No. 2, pp. 565-598.

[139] Svein-Erik, H. (2011). Breaking the "vicious cycle": Financial challenges for the opposition parties in Uganda and the role of the international community. https://www.cmi.no/file/?1319. Accessed on 04/04/2019.

[140] Takeshita, T. (2006). Current critical problems in agenda-setting research. International Journal of Public Opinion Research, Vol. 18, Issue No. 3, pp. 275-296.

[141] The Constitution of Uganda, 1995. https://www.ilo.org/dyn/natlex/docs/ELECTRONIC/44038/90491/ F206329993/UGA44038.pdf. Accessed on 23/04/2019.

[142] The Public Finance Management Act, (2015). https://www.ugandainvest.go.ug/wp-content/uploads/ 2016/02/Uganda_Public_Finance_Management_Act_2015_3.pdf. Accessed on 21/04/2019.

[143] Torill, M. (1999). The New South African Parliament: An Evaluation of Parliament's Oversight Function of the Executive. Published Master of Social Sciences in Democratic Governance Dissertation, University of Cape Town- South Africa. https://open.uct.ac.za/bitstream/handle/11427/9878/thesis_hum_1999_ monstad_t.pdf;sequence=1. Accessed on 19/03/2019.

[144] Tripp, A. M. (2004). The Politics of Constitution Making in Uganda. https://www.usip.org/sites/default/ files/Framing\%20the\%20State/Chapter6_Framing.pdf. Accessed on 19/03/2019. 
[145] Tsekpo, A., \& Hudson, A. (2009). Parliamentary strengthening and the Paris principles: Uganda case study. Overseas Development Institute, London - UK. https://www.odi.org/sites/odi.org.uk/files/odiassets/publications-opinion-files/4420.pdf. Accessed on 26/03/2019.

[146] Tsebelis, G., \& Ha, E. (2015).Coalition theory: a veto players' approach Coalition theory. European Political Science Review, pp. 1-27.

[147] Tumusiime, D. M., Mawejje, J., \& Byakagaba, P. (2016). Discovery of Oil: Community Perceptions and Expectations in Uganda's Albertine Region. Journal of Sustainable Development; Vol. 9, No. 6, pp. 1-14.

[148] Tunarosa, A., \& Glynn, M. A. (2017). Strategies of Integration in Mixed Methods Research. Organizational Research Methods, Vol. 20, Issue No. 2, pp. 224-242.

[149] Uganda Election Commission Report, (2016). 2016 General Elections Summary. Presidential Election Results. https://www.ec.or.ug/?q=2016-general-elections-summary. Accessed on 12/04/2019.

[150] Vetter, T. R. (2017). Descriptive Statistics. Descriptive Statistics: Reporting the Answers to the 5 Basic Questions of Who, What, Why, When, Where, and a Sixth, So What? International Anesthesia Research, Society, Volume XXX, Issue Number XXX, pp. 1- 6.

[151] Volpi, E. (2017). Party-Level Characteristics and Party Switching: Evidence from Twelve Western European Countries, 1988-2014. European University Institute Department of Political and Social Sciences. https://ecpr.eu/Filestore/PaperProposal/4537ac40-3fec-4f8b-a40d-ffe4dd4c0f4c.pdf. Accessed on $26 / 03 / 2019$.

[152] Walpole, J. \& Kelly, R. (2008). The Whip's Office. Parliament and Constitutional Center. House of Commons Library, London - UK.

[153] Weeks, L. (2016). Why are there Independents in Ireland? Government and Opposition, Vol. 51, Issue No. 4, pp. $580-604$.

[154] White, J. (2018). The British Academy Brian Barry prize essay: The Ethics of political Alliance. British Journal of Political Science, Vol. 48, Issue No.3. pp. 593-609.

[155] Winetrobe, B. K. (2000). Shifting control? Aspects of the Executive-Parliamentary relationship. Research Paper 00/92. Parliament and Constitution Center, House of Commons Library. http://researchbriefings. files.parliament.uk/documents/RP00-92/RP00-92.pdf. Accessed on 16/03/2019.

[156] Yamamoto, H. (2007). Tools for Parliamentary Oversight. A comparative study of 88 National Parliaments. Inter-Parliamentary Union, Geneva, Switzerland. http://archive.ipu.org/PDF/publications/ oversight08-e.pdf. Accessed on 26/03/2019.

[157] Yamane, T. (1967). Statistics an introductory analysis (2nd edition). New York: Harper and Row. http://www.sciepub.com/reference/180098. Accessed on 26/03/2019.

[158] Zalewska, M., \& Gstrein, O. J. (2013). National Parliaments and their Role in European Integration: The EU's Democratic Deficit in Times of Economic Hardship and Political Insecurity. https://www. coleurope.eu/system/files_force/research-paper/wp28_zalewskagstrein.pdf?download=1.Accessed on 26/03/2019.

[159] Zikmund, W. G. (2003). Business Research Methods. 7th Edition, Thomson/ South-Western.

[160] Zohrabi, M. (2013). Mixed Method Research: Instruments, Validity, Reliability and Reporting Findings. Theory and Practice in Language Studies, Vol. 3, No. 2, pp. 254-262.

[161] Zwibel, C. F. (2018). Platform for Participation or Political Theatre? https://www.benton.org/blog/ platform-political-theater . Accessed on 26/03/2019.

Citation: Mulyanyuma Aaron Ayeta, et.al. "Analysis of Political Parties Representation in Parliament Influence Public Policy Formulation in Uganda's Nascent Hydrocarbon Industry" International Journal of Political Science (IJPS), vol 5, no.3, 2019, pp. 14-43. doi: http://dx.doi.org/ 10.20431/2454-9452.0503002.

Copyright: (1) 2019 Authors. This is an open-access article distributed under the terms of the Creative Commons Attribution License, which permits unrestricted use, distribution, and reproduction in any medium, provided the original author and source are credited. 